\author{
Víctor Manuel Téllez Lozano ${ }^{1}$ \\ vmt198@hotmail.com \\ Cynthia Maricela Miranda García ${ }^{2}$ \\ miranda_poulain@hotmail.es \\ Víctor Manuel Fregoso García ${ }^{3}$ \\ vic_escaparate@hotmail.com \\ DOI: https://dx.doi.org/10.31836/lh.20.7092
}

\section{La construcción de paisajes políticos en la Pintura del Nuevo Reino de Galicia}

The construction of political landscapes in the Painting of the New Kingdom of Galicia

\title{
Resumen
}

Este trabajo discute la importancia de un indígena y sus prácticas culturales. De documento cartográfico del siglo XVI con influencias de los códices mesoamericaigual modo se discute cómo estos aspectos fueron convertidos por los españoles nos que muestra la transformación de un en atributos negativos que justificaban su territorio caracterizado por la resistencia conquista a toda costa.

Palabras cave: etnohistoria, códices, cartografía, resistencia indígena, Nueva Galicia.

\section{Abstract}

This article explains the importance of a $16^{\text {th }}$-century cartographic document clearly influenced by Mesoamerican codices that reveals the transformation of a territory characterized by resistance on the part of indigenous peoples and their cultural practices. It then discusses how these aspects were transformed by the Spanish into negative attributes so as to justify a conquest at any cost.

Keywords: ethnohistory, codices, cartography, indigenous resistance, Nueva Galicia.

1 3

Universidad de Guadalajara, Departamento de Estudios Socio-Urbanos. México.

Liceo 210, Zona Centro, 44100, Guadalajara, Jalisco, México.

El Colegio de Michoacán, México.

Universidad de Guadalajara, México. 


\section{Introducción ${ }^{4}$}

Este trabajo forma parte de un proyecto más amplio que tiene la intención de discutir la transformación de los paisajes políticos en el Occidente de México a partir de dos mapas del siglo xvi: la Pintura del Nuevo Reino de Galicia, Mapa del Obispado de Compostela o Mapa de Nueva Galicia, que fue enviado a España hacia 1550 y el Hispania Novae Sivae Magnae Recens et Vers Descrito o Mapa de Ortelius, elaborado en 1579. En esta ocasión abordamos la importancia del primer documento a la par de algunas relaciones y crónicas coloniales, para comprender cómo, además de ser herramientas de tipo administrativo, que permiten ampliar el conocimiento de los territorios conquistados (Anderson, 1997; Rojas, 1999), estos mapas se convierten en relatos visuales e instrumentos políticos que remarcan la otredad a partir de atributos negativos (Burke, 2001), como son la aparente ausencia de estructuras políticas, sistemas organizados de subsistencia, tributación y comercio, así como la desnudez, la belicosidad y la idolatría.

Esto remarca la idea de culturas opuestas, por lo que las culturas indígenas debían ser sometidas. Para esto se recurre a imágenes mentales presentes, de forma consciente o inconsciente, en las crónicas coloniales y que se manifiestan gráficamente en materiales tales como la Pintura (Burke, 2001). En ella, al mismo tiempo que se generan estereotipos se muestran algunos elementos característicos de las culturas indígenas de las zonas Caxcana y Nayarita, documentados por la Arqueología y la Antropología Física, que exaltan la barbarie de estas sociedades, así como la necesidad de someterlos para tomar posesión de sus territorios y explotar sus recursos. Como señala Burke (2001), estos estereotipos no son completamente falsos, pero exageran ciertos elementos de la realidad que chocan con la mirada o el punto de vista de los conquistadores.

En este sentido discutimos la importancia de la Pintura del Nuevo Reino de Galicia como una fuente de información histórica, geográfica y etnográfica, además de la posibilidad de que se trate de un códice temprano colonial, donde la perspectiva y algunos elementos estilísticos mesoamericanos se ven simplificados ante los requerimientos y las convenciones cartográficas implantadas por los conquistadores.

4

Este texto forma parte del proyecto La construcción de paisajes políticos en dos mapas del siglo XVI: La Pintura del Nuevo Reino de Galicia y el Mapa de Ortelius. 


\section{La Pintura del Nuevo Reino de Galicia o Mapa de la Nueva Galicia}

La Pintura del Nuevo Reino de Galicia, Mapa del Obispado de Compostela o Mapa de la Nueva Galicia (Imagen 1) es un documento cartográfico que se resguarda en el Archivo General de Indias, en la ciudad de Sevilla, España. Éste se encuentra en la sección de Mapas y planos de México, catalogado con el Código de referencia ES.41091.AGI/27. 17//MP-México,560, bajo el nombre de Mapa de la Nueva Galicia. Al dorso cuenta con una inscripción que lo sitúa el 8 de enero de 1550: "Todos los pueblos que tienen cruzes son de la governación de México. El liçençíado Hernando Martínez de la Marcha [alcalde mayor y visitador de Nueva Galicia que hizo información en 8 de enero de 1550]". ${ }^{5}$

\section{Imagen 1}

Pintura del Nuevo Reino de Galicia (PNRG) o Mapa de la Nueva Galicia

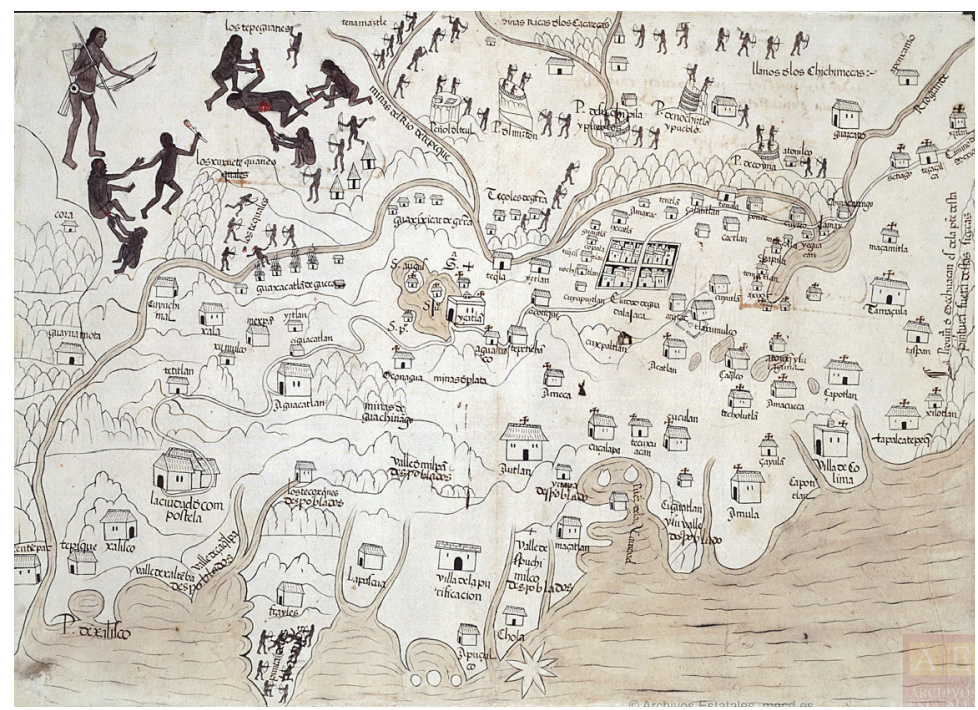

Fuente: Portal de Archivos Españoles. Ministerio de Educación, Cultura y Deporte del Gobierno de España. pañoles perteneciente al Ministerio de Educación, Cultura y Deporte del Gobierno de España. 
Se trata de un dibujo hecho a pluma sobre papel, donde predomina el color sepia, diferenciando los cuerpos de agua por su color más oscuro respecto al de la tierra, con ligeras ondulaciones que dan la impresión del flujo del agua. Mientras tanto, los caminos están caracterizados por dos líneas paralelas con un espacio más estrecho que el de los ríos y sin relleno. Por su parte, en los cuerpos humanos predomina el ocre y los detalles en rojo que representan la sangre. Sus medidas, son de 31.8 por 43.9 centímetros $^{6}$ (López Gutiérrez, 2004). Al parecer, hasta mediados de los años cincuenta del siglo $\mathrm{xx}$, su existencia era relativamente desconocida, incluso para catálogos especializados de la época, como el de Torres Lanzas, hasta que fue localizado por Dávila Garibi en el Archivo de Indias (Páez Brotchie 1957; Orendain, 1961; Pizano y Saucedo, 1964-1965).

Este mapa ha sido descrito y analizado por diferentes autores, además de aparecer en múltiples publicaciones relacionadas con la historia del Occidente de México, como: Ignacio Dávila Garibi (1922-1927), Luís Páez Brotchie (1957), la publicación Mapas Españoles de América (1951), Leopoldo I. Orendain (1961), Pizano y Saucedo (1964-1965), Gutiérrez Contreras (1979), René Acuña (1988), Weigand (1993, 2013, 2015), Weigand y García (1996, 2000, 2002a, 2002b) Yáñez (2001), López Gutiérrez (2004), Téllez (2005, 2006, 2010, 2011a, 2011b, 2011c), Hillerkuss (2006, 2013), López Guzmán (2008), Álvarez (2009, 2016), Bernabéu Albert y García Redondo (2010), Calvo y Machuca (2016), Pacheco Urista y González Rizo (2017), entre otros.

\section{Metodología}

Para analizar la Pintura del Nuevo Reino de Galicia partimos del trabajo desarrollado por René Acuña (1988), quien realizó el primer acercamiento sistemático a este mapa. Sobre los toponímicos que acompañan las ilustraciones, hizo una transcripción paleográfica con errores mínimos que se detallan en el apéndice, a los cuales hemos asignado una numeración y corregido cuando ha sido posible, para ubicarlos con mayor facilidad. Para esto, contrastamos los puntos geográficos con la cartografía de la región en mapas con escala 1: 250000 y 1: 50 000, además de que ensamblamos un rústico mapa histórico a partir de la obra de Peter $\operatorname{Gerhard}^{7}(1986,1996)$.

\begin{tabular}{l|l}
6 & $\begin{array}{l}\text { Rivera Villanueva y Berumen (2011) presentan información contradictoria respecto a } \\
\text { este documento, ya que señalan que el tamaño de este mapa es de } 318 \text { por } 439 \text { centí- } \\
\text { metros. Aunque la omisión del punto decimal puede ser un error, las medidas resultan- } \\
\text { tes equivaldrían a un impresionante mural. }\end{array}$ \\
$\begin{array}{l}\text { Aunque Marco Antonio Hernández Andrade, experto en Sistemas de Información } \\
\text { Geográfica del Colegio de Michoacán nos asesoró en el uso de mapas digitales con las }\end{array}$
\end{tabular} 
De esta forma ubicamos ciento doce elementos o toponímicos acompañados de texto en español. Estos incluyen grupos étnicos, el nombre de dos caciques (Tenamaxtli y Guaxicar), zonas mineras, cinco peñoles o sitios defensivos y el valle dominado por los Chichimecas, así como la zona dominada por los españoles. Dentro de estos elementos también se encuentran doce ríos y seis lagos o lagunas que incluimos debido a nuestro interés en la interacción de las sociedades serranas (a través de la guerra, el comercio y el tributo) con las de los valles y la costa, separadas por el Río Santiago, además de las prácticas de subsistencia que permitieron el desarrollo de diferentes tipos de organización social en las diferentes zonas que abarca este mapa.

En cuanto al orden de lectura, Acuña dividió el plano en cuatro secciones: 1Izquierda, 2 Izquierda, 3 Derecha, 4 Derecha. Esto facilita, en cierto sentido, la ubicación de los rasgos más importantes de este documento. Sin embargo, autores como Phil Weigand (1992, 1993, 2013, 2015), Weigand y García (1995, 1996, 2000, 2002a, 2002b), Medrano Enríquez (2001, 2012 , 2014) y Téllez $(2005,2006,2010,2011 a, 2011 b, 2011$ c), han prestado mayor importancia a las Zona Caxcana, la zona Transtarasca ${ }^{8}$ (especialmente en el área de Etzatlán-Magdalena) y la Zona Nayarita que, prácticamente, ocupan los sectores 1Izquierda y 3Derecha, además de algunas partes de los dos cuadrantes restantes (Imagen 2).

Uno de los planteamientos principales de este trabajo es que la Pintura del Nuevo Reino de Galicia tiene elementos representativos de un códice, aspecto que documentaremos a partir de los aportes de Joaquín Galarza $(1986,1992,1996)$, Escalante Gonzalbo $(1998,2010)$ y Mohar Betancourt $(1997,2004)$, así como los estudios realizados por los colaboradores del Proyecto Tetlacuilolli, coordinado por Mohar Betancourt. En este sentido, siguiendo el método de Joaquín Galarza y sus discípulos, como Hilda Aguirre Beltrán y Luz María Mohar Betancourt, se realizó una maqueta en que se recortó el contorno de cada elemento del mapa para poner de relieve el paisaje descrito por el tlacuilo. Esto permite apreciar los elementos geográficos, arquitectónicos y humanos que componen este documento. Por otra parte, se hizo un cuadro donde se organizan los ele-

delimitaciones geográficas planteadas por Gerhard, optamos por un mapa artesanal debido a que ciertos puntos no aparecen en la cartografía contemporánea. de los Tarascos y, hacia el norte y noroeste, con varios de los Estados Caxcanes -como Teúl, Juchipila y Nochistlán-. Durante el postclásico se convirtió en una zona de marca militar y, al iniciarse la expansión colonial se convirtió en una zona estratégica debido a su riqueza y potencial (Weigand y García, 1996). 


\section{Imagen 2}

Secciones de la Pintura del Nuevo Reino de Galicia

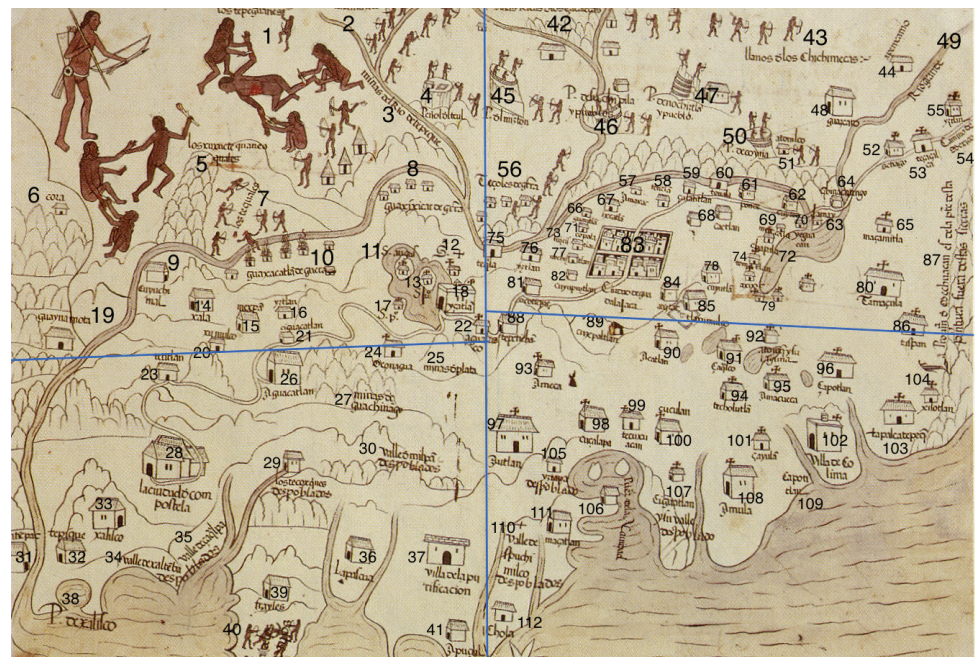

Fuente: Portal de Archivos Españoles. Ministerio de Educación, Cultura y Deporte del Gobierno de España.

mentos que consideramos comunes a otros códices elaborados durante el periodo colonial temprano, ejercicio similar al realizado por Hernández Andón (2004).

\section{La Pintura del Nuevo Reino de Galicia como un códice}

Al igual que Weigand y García (2000, 2002a) planteamos que este documento podría ser considerado como un códice que combina funciones cartográficas e históricas. En él encontramos rasgos geográficos importantes: ríos, lagos, cadenas montañosas, áreas boscosas, el contorno del Océano Pacífico y una serie de sitios defensivos. Apoyados por la revisión documental y la lectura del paisaje, a lo largo del texto presentamos la correspondencia de los cuerpos de agua con la geografía contemporánea, lo que permitirá discutir, en textos posteriores, cómo estos entornos fueron aprovechados por las sociedades indígenas, sin olvidar las transformaciones a las que se vieron sometidas en siglos posteriores. Esta misma metodología deberá ser aplicada a las cadenas montañosas. Aunque sus ilustraciones no son necesariamente realistas, la perspectiva mesoamericana, comprimida en la Pintura, nos permite vislumbrar, en un estilo que 


\section{Imagen 3}

Diagramas 1 y 2: orientación occidental y orientación mesoamericana

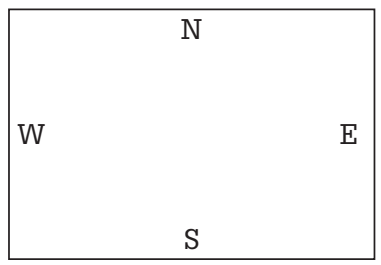

(Diagrama 1)

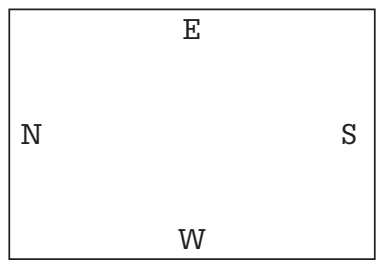

(Diagrama 2)

Fuente: Portal de Archivos Españoles. Ministerio de Educación, Cultura y Deporte del Gobierno de España.

incluye ciertas convenciones europeas (como el uso de textos en caracteres latinos, ciertas representaciones arquitectónicas), el paisaje visto (y descrito) por su autor.

Es necesario considerar que la perspectiva mesoamericana en los códices cartográficos difiere de la perspectiva occidental (Norte/ Sur, Este/ Oeste), lo que dificultaría su lectura a las personas poco familiarizadas con estos materiales. De este modo, la orientación de la Pintura debe analizarse de la siguiente manera: Este/ Oeste, Norte/ Sur (Imagen 3: Diagramas 1 y 2). Si consideramos que el norte se encuentra en su extremo izquierdo, esta es bastante precisa en la localización de los ríos, la distribución de los grupos étnicos y los asentamientos españoles. Así, podemos identificar fácilmente los ríos Grande de Santiago, el Tepeque (Bolaños), el Río de Juchipila, al igual que la ubicación de la Provincia de Michoacán, el lago de Chapala y las ciudades de Compostela y Guadalajara (unidas por el camino que lleva a la ciudad de México). Hacia el Océano Pacífico, contrastando la desembocadura de los ríos con la ubicación de los puntos señalados en el mapa, ubicamos los ríos Ameca, Mascota, Tomatlán, San Nicolás, Preciado, Cuzamala, Marabasco, Armería y Coahuayana. A partir de esto, la mayoría de los asentamientos, concuerdan con su ubicación espacial en la cartografía contemporánea, aunque existen algunas adaptaciones espaciales y errores de ubicación que se detallarán más adelante, al abordar su precisión geográfica.

El estudio realizado por Bernabéu Albert y García Redondo (2010) argumenta que hay elementos estilísticos que permiten sostener la manufactura española de este documento, mientras que Weigand y García han defendido sus influencias mesoamericanas (Weigand, 2015b; Weigand y 
García, 1996, 2000, 2002a, 2002b), al mismo tiempo que Hillerkuss (2013) piensa que cuenta con elementos prehispánicos. Podría considerarse que al situar este documento entre la cuarta y la quinta década del siglo XVI estamos hablando de un tlacuilo altamente aculturado para una etapa tan temprana, más cercano a una tradición más occidental que mesoamericana. Sin embargo, desde los primeros años de la colonia los indígenas estuvieron en contacto con el estilo europeo a través de las imágenes religiosas utilizadas para la evangelización, además de que en las escuelas conventuales se enseñaba a los indígenas a dibujar y pintar al estilo europeo por lo menos desde 1526 (Robertson, 1994; Escalante Gonzalbo, 2010). ${ }^{9}$

A partir de 1532, durante la Segunda Audiencia de la Nueva España los códices cobraron importancia como fuentes de información, al mismo tiempo que se realizaban las primeras descripciones geográficas, demográficas y económicas de la Nueva España en función de los repartimientos (Baudot, 1983, 1990; Escalante Gonzalbo, 2010). Por otra parte, en 1534 el Rey de España solicitó a la Audiencia que hiciera "pintar toda esa Nueva España, sus provincias y cabeceras", solicitud que se repite entre 1535 y 1536 y donde se recurrió al servicio de los tlacuilos (Puga, 1985, citado en: Escalante Gonzalbo, 2010: 117).

Aparentemente no existen elementos característicos de los códices mesoamericanos, como los glifos o colores representativos de otros documentos prehispánicos o coloniales tempranos (como el Códice Mendocino o el Telleriano Remensis, etc.). A partir de las consideraciones de autores como Galarza (1996) y Escalante Gonzalbo (1998, 2010) proponemos que en la Pintura existen elementos mesoamericanos conjugados con nuevas representaciones gráficas e, incluso, una nueva perspectiva. En este sentido, la Pintura podría ser uno de los primeros ejemplos de experimentación al utilizar elementos estilísticos e iconográficos indígenas subordinados a un formato y una función específica: un mapa de cam-

En 1527, se fundó la escuela de San José de los Naturales, anexa al convento de San Francisco, donde se enseñaban diferentes oficios ligados con las artes mecánicas, pero también se aprovechaban las tradiciones artísticas indígenas, lo que implicaba adaptar las prácticas indígenas al gusto occidental. Aunque no hay registro de que se hayan pintado códices en esta escuela, debemos considerar su influencia sobre el estilo de sus alumnos, como Fray Diego Valadéz. Por otro lado, en 1536 se fundó el Colegio de Santa Cruz de Tlatelolco, que jugó un papel importante en el desarrollo del estilo colonial temprano en la pintura de manuscritos. A diferencia del Colegio de San José, en Tlatelolco se impartían estudios superiores, aunque es posible que algunos de sus alumnos supieran pintar (Broda, 1978; Escalante Gonzalbo, 2010). 
paña convertido en un documento de carácter informativo que, al mismo tiempo que condensa un conocimiento cartográfico en ciernes, describe gráficamente una serie de eventos que afectaron la región.

Por ejemplo, en las construcciones podemos distinguir entre las que conservan el estilo indígena y otras cuyo dibujo y perspectiva da la impresión de volumen y dirección. Algunas de estas incluso representan edificaciones compuestas, como el templo de la Villa de Colima y el convento de Etzatlán, que cuentan con cúpulas. Este recurso se hace presente, de forma predominante en el Mapa del pueblo de Cuzcatlan, Diocesis de Tlaxcala (en Morales Folguera, 2003: 46), elaborado en 1580, al mismo tiempo que convive con la orientación mesoamericana, elementos glíficos y la representación prehispánica de los ríos (Imagen 4). Otra estructura compuesta corresponde a la ciudad de Compostela, mostrada como tres

\section{Imagen 4}

Mapa del pueblo de Cuzcatlan, Diocesis de Tlaxcala

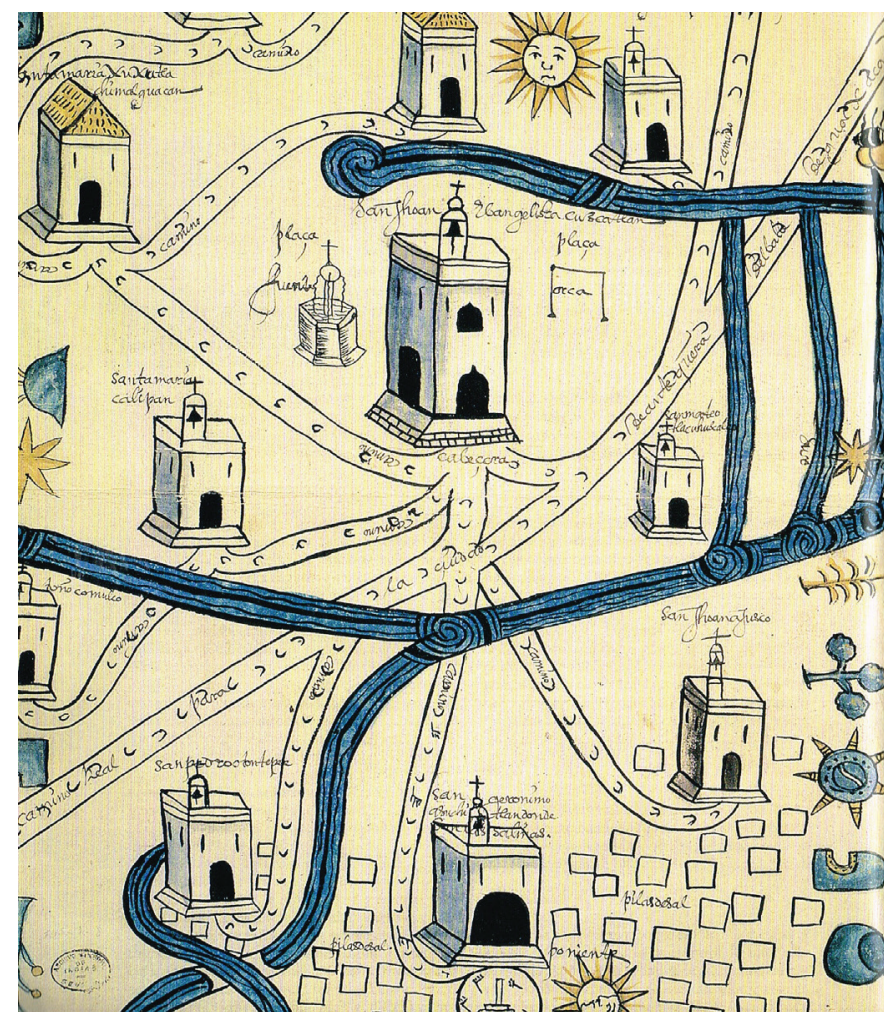

Fuente: Tomado de Morales Folguera, 2003, p. 46. 
casas con techo de paja, una detrás de la otra que, solo por su tamaño y el señalamiento de que se trata de una ciudad, nos permite entender la relativa importancia de este asentamiento. Mención aparte merece la concentración urbana que representa a Guadalajara, que nos muestra una (hipotética) ciudad relativamente populosa y organizada, aspecto que será analizado posteriormente. Bernabéu Albert y García Redondo (2010) consideran que estas estructuras, junto a Purificación (representada por una estructura más sencilla que muestra una especie de friso o enladrillado superior), corresponden a posibles diseños hispánicos.

En contraste, nos encontramos con otras representaciones de casas que aparecen frontalmente, sin volumen aparente (lo que se aplica a la construción que representa a Purificación), algunas de ellas rematadas con una cruz (como las de Tamazula, Tuxpan, Autlán, todas ellas pertenecientes a la Provincia de Ávalos, bajo la administración de la Nueva España) o con pequeñas ventanas. De igual modo, existen construcciones del mismo tipo, pero sin ventanas, especialmente a lo largo del Río Santiago, en las zonas Nayarita, Cuana y Caxcana, pero también bordeando a la ciudad de Guadalajara. Estas corresponden a una de las variantes mesoamericanas del glifo calli (casa), específicamente al Huey Calli o casa grande (Galarza, 1996), aunque simplificada, seguramente por el tamaño del documento en cuestión (Imagen 5).

Puede parecer contradictorio señalar la presencia de diseños europeos y mesoamericanos en lo que proponemos como un códice colonial temprano. Sin embargo, como se mencionó previamente, desde 1526 se promovió la enseñanza del estilo europeo entre los indígenas. Los nuevos tlacuilos empezaron a dibujar paisajes copiados de estampas y libros de origen europeo que, al plasmarse en documentos pictográficos, generaban escenarios inexistentes en el paisaje mexicano de la época, tal como

\section{Imagen 5}

Calli
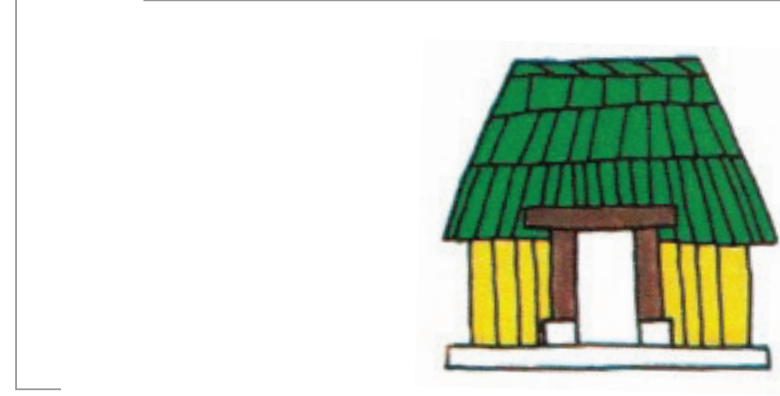

Fuente: Tomado de Galarza (1996). 
sucede en las ilustraciones que acompañan las obras de Sahagún y Durán (Escalante Gonzalbo, 2010).

En la Pintura esto se aplica específicamente a las imágenes de Colima, Etzatlán y especialmente a Guadalajara, representada con la traza urbana de una ciudad europea. Al mismo tiempo apreciamos imágenes sin volumen, propias de los códices, pero también una que podríamos considerar como altamente experimental, como la representación de Tlajomulco, donde la edificación principal muestra profundidad mientras el atrio se ve como un marco colocado de forma relativamente arbitraria al mismo tiempo que la cruz central se encuentra recostada. Sin embargo, al elevar estos elementos (la capilla y la cruz), encontramos una correspondencia con la perspectiva mesoamericana.

Otro elemento que nos hace pensar en su elaboración indígena, influida por la enseñanza misionera, se relaciona con las figuras humanas que aparecen en él. En este contexto, los misioneros consideraban las proporciones de la tradición Mixteca-Puebla utilizadas en los códices como feas, imperfectas o poco realistas, debido a que las figuras humanas eran iguales y carecían de rasgos individuales. Las diferencias se marcaban en atributos como la ropa, tocado, postura, y los glifos correspondientes a cada uno. Además, la estructura anatómica y las posturas carecían de la naturalidad propia de la perspectiva occidental, de tal modo que modo que siempre se plasmaban figuras rígidas que parecían carecer de peso, como si estuvieran suspendidas sobre el papel, mientras que piernas y brazos no muestran variaciones de grosor (Galarza, 1986, 1992, 1996; Mohar Betancourt, 1997, 2004; Escalante Gonzalbo, 2010).

De igual modo, los personajes que aparecen de pie siempre parecen caminar porque sus piernas se muestran abiertas en compas, una postura que permitía a los tlacuilos mantener un estereotipo propio de la tradición Mixteca-Puebla: mostrar la figura humana de perfil al mismo tiempo que indica una actividad: servir de embajadores, peregrinar, llevar ofrendas o, en el caso de la Pintura, ir a la guerra (Escalante Gonzalbo, 2010).

Si seguimos las ideas de Galarza (1986, 1992, 1996), las imágenes de mayor tamaño, que representan a un guerrero y dos escenas de sacrificios humanos en el extremo superior izquierdo, por su importancia marcarían el orden de lectura de este documento como códice. En él las figuras humanas muestran una posición relativamente naturalista y, aunque entre los guerreros predomina el perfil, en algunas figuras el tronco se presenta ligeramente de frente, algo común en los códices elaborados durante el periodo colonial (Escalante Gonzalbo, 2010). Como elementos de la antigua tradición, en las imágenes de mayor tamaño (el guerrero que se encuentra en el extremo superior izquierdo y las escenas de sa- 
crificio humano que le acompañan), predominan narices más o menos prominentes en los rostros que se ven de perfil, no existen orejas, invariablemente cubiertas por el cabello ${ }^{10}$, aunque las cejas y los ojos presentan cierto nivel de detalle introducido por los españoles.

Dos de estos personajes (el que aporrea a uno de los sacrificados y uno de los que están desollando a una víctima ya muerta) muestran su rostro en tres cuartos y con cierta profundidad que no existe en el resto, además de que sus cuerpos muestran cierta tendencia al contraposto. Esto último también se aplica al guerrero de menor tamaño que se encuentra a la derecha de la inscripción de los tepeguanes. A diferencia de la TradiciónMixteca-Puebla, los músculos se definen en cierta medida, además de que apreciamos una ligera flexión de rodillas en los personajes que se encuentran de pie. Esto no sería casual si consideramos que la mayoría de los indígenas del centro de México estaban dispuestos a aprender nuevas técnicas y oficios, cosa que hacían con cierta rapidez debido a que en la época prehispánica existía una tradición educativa exigente que, aunada a la capacidad de observación permitió integrar nuevos elementos a los códices al mismo tiempo que se mantienen ciertos estereotipos modificados por nuevas influencias estilísticas, aunque predomina rigidez propia de la antigua tradición pictográfica ${ }^{11}$ (Motolinía, 1984; Escalante Gonzalbo, 2010; López Austin, 1985).

Específicamente nos referimos a dos personajes en posición sedente que se encuentran en el ángulo superior izquierdo, desollando a las víctimas del sacrificio. Aunque aparecen completamente desnudos, su postura anatómica nos remite en cierta medida a los glifos que representan a personajes sentados al estilo indígena: el trasero sobre el piso o un equipal y las rodillas cercanas al pecho, talones cercanos al trasero mientras que las plantas de los pies se encuentran en contacto con el piso o el asiento. Los brazos pueden quedar apoyados sobre las rodillas o abrazando las espinillas comprimiendo aún más las piernas contra el pecho, una postura frecuente en la escultura prehispánica mexica. Una variante consiste en colocar las piernas en ángulo recto de tal modo que los muslos quedan paralelos a la superficie del asiento, como puede apreciarse

10 Las ilustraciones que compañan la obra de Hans Staden (1557) prestan cierta atención a las orejas, aunque solo algunas imágenes femeninas las ocultan bajo la cabellera (Bustamante, 2009, Contreras, 2014)

11 Uno de los principales ejemplos de la experimentación entre elementos que brindan profundidad al paisaje, al mismo tiempo que las figuras humanas muestran rigidez a pesar de mostrarse en escorzo o de espalda es el códice Azcatitlan (Escalante Gonzalbo, 2010). 


\section{Imagen 6}

Detalle de la lámina 79 del

Códice Nuttall que muestra las dos posturas sedentes al estilo indígena

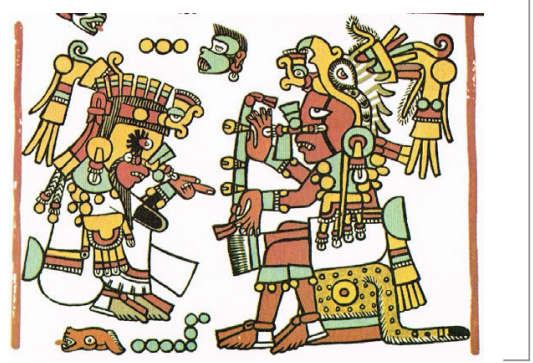

Fuente: Tomado de Nuttall (1975).

\section{Imagen 7}

Hombres sentados en el

Códice Magliabecchi

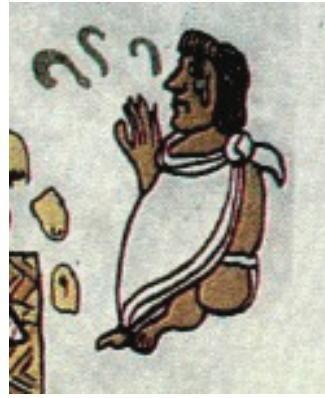

Fuente: Tomado de Galarza (1990, p. 180).

en la lámina 79 del Códice Nuttall (Imagen 6) (Nuttall, 1975; Escalante Gonzalbo, 2010).

En los códices coloniales predomina la primera postura, independientemente de estar sentados sobre equipales. Al representar a las figuras con su manto impide saber si abrazan las piernas, se apoyan sobre ellas o colocan los brazos de otra manera, como sucede en el Códice Magliabecchi, el Códice Mendocino, la Tira de la Peregrinación o el Códice Mapa Quinatzi (Galarza, 1986, 1992; Mohar Betancourt, 1997, 2004) (Imagen 7). En el documento que nos ocupa se aprecia la primera postura en dos variantes: un personaje mostrado de perfil aunque tronco y piernas giran levemente hacia el frente en la escena donde una víctima está próxima a ser ejecutada y uno más conservador que se encuentra completamente de perfil frente a una víctima ya fallecida. En este caso, la desnudez de los personajes, así como la intención de las imágenes nos permite ver los brazos proyectados hacia el frente mientras se enfocan en desollar a sus víctimas. En cambio, sus compañeros de faena muestran posturas relativamente más realistas, más cercanas a representaciones más tardías, como la del Códice Vaticano (circa 1566).

Un elemento que no podemos dejar de lado tiene que ver con la imagen de la víctima de sacrificio que está siendo desollada bajo la denominación de los tepeguanes. Como se ha mencionado, en general las imágenes humanas de los códices parecen flotar sobre la superficie de estos documentos. Sin embargo, al representar una muerte violenta el cuerpo humano se muestra en una especie de movimiento congelado, suspendido en el aire, y con el ojo cerrado, como sucede en el Códice Nuttall, lámina 76 (Imagen 8) y el Telleriano Remensis, fol. 28v,32r, 38v,46r. Esto se aplica a la imagen 
Imagen 8

Detalle de la lámina 76 del Códice Nuttall que representa una muerte violenta

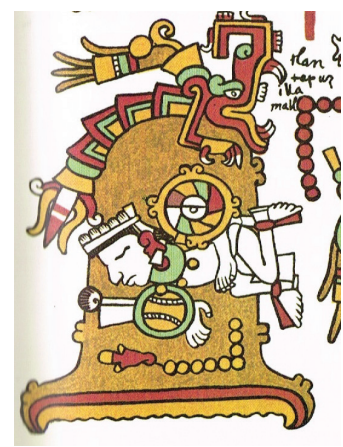

Fuente: Tomado de Nuttall (1975).
Imagen 9

Petrograbados analizados por Hers en Las Adjuntas, barranca

del Río Chapalagana

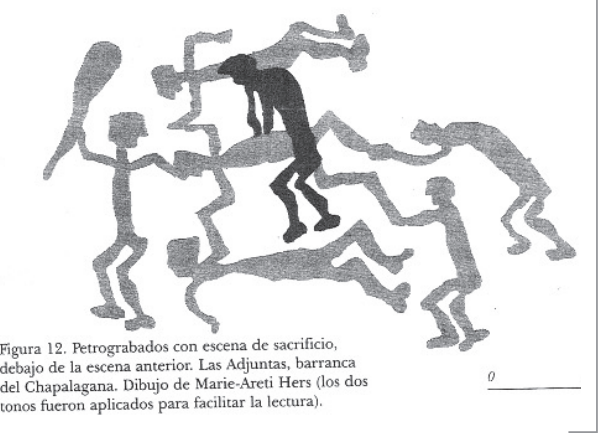

Fuente: Tomado de Hers (2010).

mencionada, salvo que en este caso la víctima se encuentra sostenida por sus victimarios. En estas escenas encontramos reminiscencias de los códices, pero también de petroglifos como los documentados por Hers en la barranca del río Chapalagana (Hers, 2008: 25; 2010: 237) (Imagen 9).

Estos elementos pasan casi desapercibidos debido al relativo realismo de las imágenes de los sacrificios, además de que se encuentran supeditados al marco geográfico enmarcado por el Río Grande y el contorno del Océano Pacífico, elementos que en un códice formal deberían aparecer en color turquesa. Ante esto, podemos suponer que su elaboración fue supervisada por un europeo interesado más en los datos geográficos de un espacio desconocido hasta entonces para los conquistadores.

Junto a los sacrificios humanos, una particularidad de la Pintura del Nuevo Reino de Galicia es que las escenas bélicas, que ocupan la parte superior, representan el enfrentamiento entre indios flecheros: unos empeñolados, en posición defensiva y otros en posición de ataque contra los primeros. Al considerar a la Pintura como un códice, pero también como un relato histórico que puede remitirnos a un pasado relativamente remoto, mantenemos la posibilidad de que en un solo espacio se sinteticen dos momentos importantes en la historia de la región: por un lado, la expansión de los Estados Caxcanes durante la época prehispánica, aproximadamente en el siglo XIII (Tello, 1968; Weigand, 1993, 2015; Weigand y García, 1995, 1996, 2002a). Por otro, el pasado reciente con las batallas libradas para sofocar la Guerra del Mixtón, entre 1541 y 1542, donde participó un gran número de indígenas del centro de México como aliados de 
las tropas españolas, además de la conflictiva situación prevaleciente en las zonas de Guaxacatlán y Guaxixicar, pero sobre todo las amenazas que dificultaron la exploración y el tránsito de los españoles hacia las zonas de donde provenía la plata que formaba parte de los tributos prehispánicos.

Así, salvo estas últimas zonas, gráficamente observamos que el Río Santiago se convierte en un límite natural entre las sociedades indígenas que resisten el avance de los conquistadores, y tratan de mantener el control sobre su antiguo territorio, a la vez que el avance colonizador es fácilmente reconocible por el detalle de la arquitectura, fundamentalmente religiosa en Etzatlán (Yzatlán) y Colima, así como la concentración urbana en Compostela y Guadalajara.

En síntesis, consideramos que este es un documento cartográfico de origen colonial, pero con una fuerte influencia de los códices mesoamericanos, evidente en la perspectiva, organización y variación del tamaño de los elementos que lo conforman. Algunos de estos serían: la presencia de algunas convenciones propias de la escritura glífica (calli-casa, la postura anatómica de los personajes), así como anotaciones latinas, características que lo acercarían a lo que Galarza define como códices mixtos (Galarza, 1990).

Como se mencionó previamente sobre la orientación, predomina la perspectiva mesoamericana, donde el oriente se encuentra en la parte superior y el poniente en la inferior. Aunque se ha sugerido que en la parte inferior hay algo que podría interpretarse como una burda estrella de los vientos (Calvo y Machuca, 2016), consideramos que más bien se trata de un glifo solar sumamente simplificado respecto a la Tradición MixtecaPuebla, convenientemente situado al poniente, descansando en el Océano Pacífico. Esta representación puede representar un tipo de transición entre la tradición mesoamericana y la posterior representación del sol con un rostro humano, inspirado en ilustraciones europeas, que apreciamos en códices como el Telleriano-Remensis (1566) o el ya mencionado Mapa del pueblo de Cuzcatlan (1580). De hecho, en este mapa se representan el oriente y el poniente, hacia arriba y abajo, representados por el sol y la luna con rostros humanos, mientras que el norte y el sur se representan por estrellas muy similares a la que se vemos en la Pintura del Nuevo Reino de Galicia. ${ }^{12}$

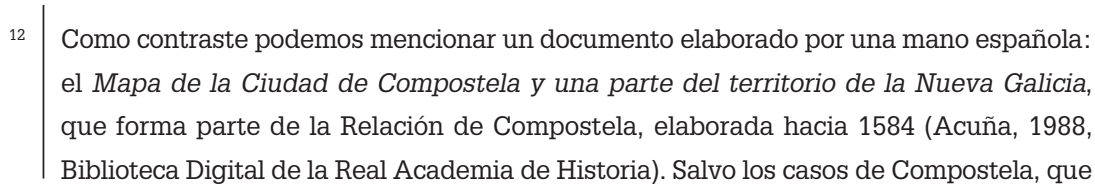




\section{Imagen 10}

Bosques y atados de plumas. Códice Mendoza o Mendocino (lámina M_47r)

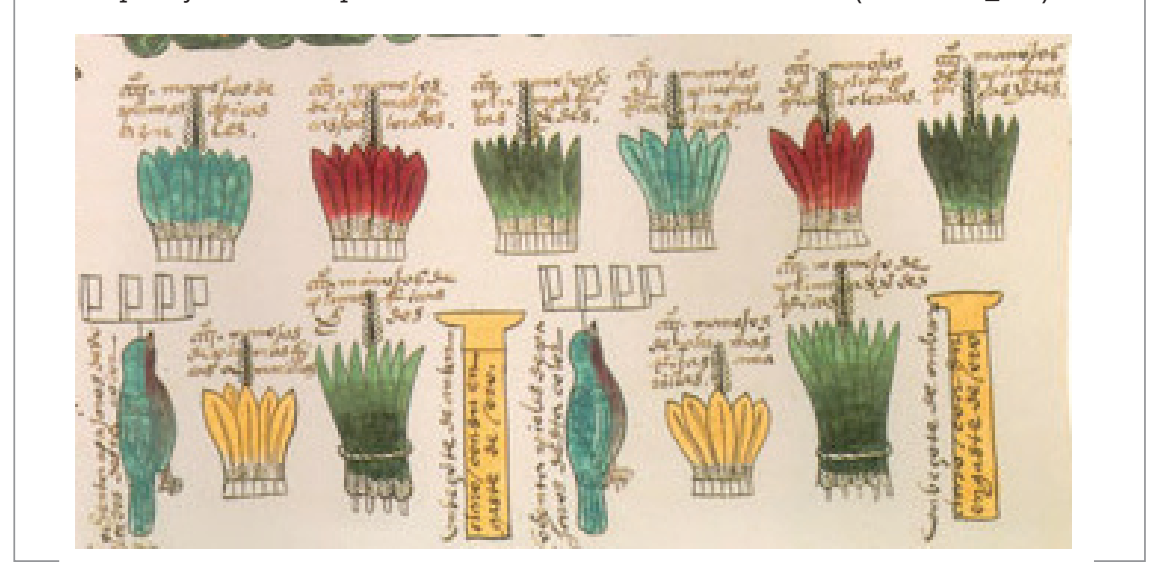

Fuente: Tomado de Crespo (s/f).

En cuanto a las serranías y cuerpos montañosos son representados de dos formas: por un lado con una serie de elementos que podríamos interpretar como bosques que estilísticamente tienen cierta relación con el remate de los atados de plumas representados en el Códice Mendoza o Mendocino, específicamente en la lámina M_47r (Galindo y Villa, 1980; Mohar Betancourt, 1997: 98; Crespo, s/ f) (Imagen 10). Por otro, encontramos el perfil de cuerpos montañosos que parecen corresponder a cadenas montañosas más pequeñas o específicas. Especialmente en el primero de estos ejemplos se aprecia un amontonamiento, recurso propio de las ilustraciones góticas del siglo XV para mostrar una concentración de elementos. ${ }^{13}$

es mostrada como una estructura arquitectónica de mayores dimensiones y Santiago Temichoque, como una representación muy cercana al Huey Calli, el resto de los asentamientos son mostrados con sencillas imágenes que figuran torres rematadas en cruz con cierta uniformidad. Todas estas estructuras y el texto muestran la misma orientación, de frente hacia el norte que, en este documento se encuentra en la parte inferior. En este ejemplo, la orientación del documento es bastante clara gracias a la presencia de flores de lis que marcan cada punto cardinal.

13 El Mapa de la Ciudad de Compostela muestra la serranía como una serie de trazos ondulados en diferentes sentidos (Acuña, 1988; Biblioteca Digital de la Real Academia de Historia). 


\section{Fecha de realización}

Como se mencionó previamente, la clasificación del Portal de Archivos Españoles nos indica que este documento fue enviado a España por Hernán Martínez de la Marcha el 8 de enero de 1550. Para los historiadores, este es un dato incontrovertible: a partir del mismo, la mayoría de los autores plantean la posibilidad de que la Pintura hubiera sido realizada hacia 1550, por un autor anónimo (Pizano y Saucedo, 1964-1965) o atribuyendo su autoría, o por lo menos el encargo de su realización, a Hernando Martínez de la Marcha (Orendain, 1961; Yáñez, 2001; Pedro González, información personal; Hillerkuss, 2006, 2013 e información personal; Bernabéu Albert y García Redondo, 2010; Calvo y Machuca, 2016; Álvarez, 2016). Esto se debe a que Martínez de la Marcha, Oidor alcalde mayor de la Nueva Galicia realizó un recorrido que fue detallado en la Suma de su visita general a lo largo de 1550. De hecho, parecería que la Pintura es resultado de su recorrido ${ }^{14}$ (Parry, 1993; Sarabia Viejo y Román Gutiérrez, 1992; Román Gutiérrez, 1993; León Portilla, 1995; Carrillo Cázares, 2000; Yáñez 2001: 82, 94; Hillerkuss, 2006, 2013; Bernabéu Albert y García Redondo, 2010; Calvo y Machuca, 2016; Álvarez, 2016).

Por otra parte, autores como Acuña (1988) o Weigand y García (Weigand 1992, 1993, 2015b; Weigand y García 1996, 2000, 2002a, 2002b), han cuestionado la autoría y la fecha de realización de este documento. Acuña (1998) considera que la Pintura pudo ser elaborada entre 1541 y 1546, un periodo que abarcaría la Guerra del Mixtón, representada por las escenas de guerra, y el "descubrimiento" de las minas ricas de los Zacatecas por parte de los españoles. En tanto, Weigand y García sugieren que data de una fecha muy cercana a 1542, pero anterior a 1546, además de que han enfatizado las influencias mesoamericanas de este documento (Weigand, 2015b; Weigand y García, 1996, 2000, 2002a, 2002b). Por su parte, Hillerkuss (2013) piensa que la Pintura fue confeccionada con elementos prehispánicos, aunque sostiene la idea de que fue realizado entre 1550 y principios de 1551. Por nuestra parte, consideramos la posibilidad de que este documento fuera elaborado poco después de 1542, pero antes de 1550.

Martínez de la Marcha fue nombrado Oidor de la Audiencia de la Nueva Galicia (junto a Jerónimo Lebrón de Quiñones, Miguel de Contreras L. De Guevara y Juan Meléndez de Sepúlveda) el 21 de mayo de 1547

$14 \begin{aligned} & \text { Martínez de la Marcha fue acompañada por dos escribanos (Bernal Pies y Esteban de } \\ & \text { Marván) y una persona iniciada en el dibujo y la arquitectura (Bernabéu Albert y García } \\ & \text { Redondo, 2010) }\end{aligned}$ 
(Enciso Contreras, 2016: 17). ${ }^{15}$ Llegó a Compostela en otoño de 1549 y el 28 de Noviembre de ese año se realizó el primer reporte oficial de la Audiencia (Parry, 1993: 90). Posteriormente, Martínez de la Marcha realizaría su visita general, que incluyó los principales asentamientos y villas de españoles. Su visita se inició el tres de diciembre de 1549 y terminó el siete de diciembre de 1550, como se menciona en su carta al rey de España, escrita el 18 de febrero de 1551. Esta carta incluye abundante información sobre la organización política de las zonas Caxcana y Nayarita, como el nombre de los caciques indígenas, sus alianzas militares e incursiones contra pueblos pacificados (Martínez de la Marcha, 2000). Durante la misma, atestiguó litigios, residencias y cuentas, además de que instituyó una serie de ordenanzas que dotaron de amplias facultades y prerrogativas a los alcaldes mayores de minas en Zacatecas, además del levantamiento de censos y establecimiento de ordenanzas en los reales de minas de Zacatecas y Guachinango, ${ }^{16}$ (Parry, 1993: 95; Bernabéu Albert y García Redondo, 2010; Enciso Contreras, 2016: 17). ${ }^{17}$

Si consideramos las fechas mencionadas, así como la incluida por el Portal de Archivos Españoles (8 de enero de 1550), casi un mes después de iniciado su recorrido alrededor de Guadalajara, donde se estableció hasta marzo de 1550 (Bernabéu Albert y García Redondo, 2010 ), podemos pensar que la última podría corresponder a la fecha de envío del primer informe de la Audiencia a tierras españolas, un tiempo relativamente breve para elaborar un mapa con tal cantidad de detalles ${ }^{18}$. De hecho, en el primer párrafo de la carta de 1551, hace alusión a este reporte realizado después de asentarse la Real Audiencia en Compostela, "enviada conjuntamente con ciertas informaciones y pintura de la tierra y testimonios, todo a V.M." (Martínez de la Marcha, 2000: 479). Esto nos da la pauta para considerar la posibilidad de que el mapa haya sido elaborado en años anteriores y fuera obtenido por Martínez de la Marcha durante su visita a la Nueva Galicia y lo incluyera en el reporte de la Audiencia. ${ }^{19}$ Incluso es

15

16

17

19

Parry indica que el nombramiento se hizo en 1548 (Parry, 1993).

En ese mismo año, Juanes de Tolosa, que había participado en la Guerra del Mixtón y

el "descubrimiento" de las minas de Zacatecas comprobó sus méritos ante Martínez de la Marcha (Rojas, 1994).

Al año siguiente, Miguel de Contreras y Lorenzo Lebrón de Quiñones realizaron sus visitas a las zonas aledañas a la Mar del Sur (Parry, 1993: 98; Enciso Contreras, 2016: 17).

Recordemos que el informe fue realizado el 28 de Noviembre de 1549.

Sarabia Viejo y Román Gutiérrez, 1992; León Portilla (1995), así como Hillerkuss (2013), mencionan la existencia de otras tres pinturas, hoy en día desaparecidas. 
posible que Martínez de la Marcha actualizara la información contenida en el mapa señalando zonas mineras y asentamientos despoblados, lo que se puede inferir en algunos rasgos de escritura.

Consideramos la posibilidad de que la Pintura del Nuevo Reino de Galicia fuera elaborada algunos años antes de 1550 por un indígena del centro de México que hubiera acompañado a las tropas virreinales durante la Guerra del Mixtón. A esto sumamos la idea de que pudo ser encargada por Pedro Gómez de Maraver, uno de los principales testigos de los hechos acontecidos en esta época: como Deán de Oaxaca acompañó al Virrey Antonio de Mendoza como consultor sobre el carácter de la guerra durante la campaña para sofocar la Rebelión de la Nueva Galicia (Ruiz Medrano, 1994a; Carrillo Cázares, Vol II, 2000).

Esto le permitió participar en las Juntas Eclesiásticas de 1544, donde hizo notar que "los yndios están mui diestros en la guerra" (Gómez de Maraver en: Carrillo Cázares, Vol II, 2000: 463), además de promover la causa de la guerra justa, las incursiones en las zonas fronterizas y la esclavitud de los indios capturados en ellas. Aunque su postura contravenía la Cédula Real, emitida por Carlos V en 1530, era considerada como necesaria por este personaje debido a las "grandes osadías y maldades y acometimientos que los naturales cometieron después que se levantaron" (Gómez de Maraver en: Carrillo Cázares, Vol II, 2000: 476), situación que fue aprovechada por el mismo virrey, así como mineros de Taxco y Sultepec apoyados por Gómez de Maraver (Ruíz Medrano, 1994). De igual modo, para fortalecer la presencia española en la región, defendió los intereses de colonizadores, encomenderos, mineros y comerciantes afectados por las Leyes Nuevas de 1542, postura que compartiría con el Virrey de Mendoza y, posteriormente con Martínez de la Marcha ${ }^{20}$ (Ruiz Medrano, 1994a; Carrillo Cázares, 2000; Bernabéu Albert y García Redondo, 2010).

Esto, aunado a sus denuncias sobre la destrucción de templos católicos y la muerte de misioneros, debió influir en su designación como primer obispo de Compostela en 1548 (aunque estableció su sede en Guadalajara) y desde ese momento solicitó la definición de los límites del nuevo obispado, lo que ocasionó en lo sucesivo una querella con Vasco de Quiroga, Obispo de Michoacán, por el alcance de sus jurisdicciones en la que recibió el apoyo del virrey de Mendoza (Sarabia Viejo y Román Gutiérrez, 1992; Parry, 1993; Ruiz Medrano, 1994a; Carrillo Cázares, 2000; Yáñez, 2001).

$20 \mid \begin{aligned} & \text { La política esclavista en la región se prohibió nuevamente hacia } 1548 \text { (Bernabéu Albert } \\ & \text { y García Redondo, 2010). }\end{aligned}$ 
Estas preocupaciones pudieron inspirar la elaboración de este mapa, un retrato de la dinámica política y territorial del Occidente de México a mediados del siglo XVI y que guarda estrecha relación la Rebelión de la Nueva Galicia (1532-1542), especialmente con los hechos ocurridos en la zona Caxcana entre 1541 y 1542, cuando se desarrolló la campaña militar más importante en la región: la organizada por el virrey Antonio de Mendoza para sofocar la Guerra del Mixtón. Así, podemos apreciar varios peñoles y pueblos en pie de guerra en las zonas Caxcana y Transtarasca. Estos peñoles son los de Coyna, Nochistlán, Juchipila, El Mixtón y el Teúl, mismos que fueron sometidos, uno a uno, entre los meses de septiembre y diciembre de 1541 (Ruiz Medrano, 1994a, Yáñez, 2001, Tello, 1973).

También debemos considerar que en este mapa se aprecia la importancia de caciques como Tenamaxtli y Guaxicar, que gracias a las alianzas con otros caciques regionales, se mantuvieron en pie de guerra por lo menos hasta 1551 como parte de lo que conocemos como la Guerra Chichimeca (Martínez de la Marcha, 2000; Carrillo Cázares, Vol. I, 2000, Weigand, 1993, 2013, 2015b; Weigand y García, 1996, 2000, 2002a). Esto explicaría la referencia a Tenamaxtli refugiándose en la serranía, situación que se prolongaría hasta marzo de 1551, cuando se entregó voluntariamente a los franciscanos (León Portilla, 1995; Carrillo Cázarez, 2000) .

Conviene considerar algunas de las ideas que pudieron influir para que Acuña (1988), Weigand y García (Weigand, 1993; Weigand y García, 1996, 2002b) plantearan que este mapa fue realizado entre 1541-42 y 1546, mismas que se relacionan con la descripción de asentamientos mineros como el de Guachinango, cuyo Real data de 1544 (Hillerkuss, 2013) y las minas de plata en las cercanías de Etzatlán, en la zona Transtarasca, cuyas fundaciones españolas son anteriores a 1546, ademas de Zacatecas y Tepeque entre las zonas Caxcana y Nayarita. Algunos autores sugieren que la definición de las Minas ricas de los Zacatecas implica la realización de la Pintura después de la fundación del asentamiento español del mismo nombre (Acuña, 1988; Hillerkuss 2006). Sin embargo, la referencia a los Zacatecas, la representación de los indios flecheros en pie de guerra y una construcción de techo cónico, aunada a la evidencia de una tradición minera desde la época prehispánica, podrían indicar la presencia de este grupo étnico y no de un asentamiento colonial, claramente diferenciado en este documento (Weigand 1992, 1993, 2015b; Weigand y García, 1996).

A esto debemos sumar que la obtención de oro y plata en Mesoamérica y Perú era una práctica que sólo se realizaba en ciertas épocas del año, generalmente para hacer ornamentos. Aunque estos minerales no tenían el valor económico atribuido por los europeos (Taussigg, 1993), el oro de la zona centro-oriente de Durango (Langenscheidt, 2009) y la plata obte- 
nida en las zonas de Tepeque y Zacatecas formaban parte del comercio y tributo prehispánico, aunque con una importancia menor respecto a la minería para la obtención de chalchihuites, hematita, malaquita, azurita, pedernal, cuarzo, obsidiana, etc., productos provenientes de yacimientos de diferentes zonas como Nuevo México, Arizona, la zona de Chalchihuites, o la zona de Teuchitlán-Ahualulco (Cabrero, 1992; Weigand, 1993; Weigand y García, 1996, 2002b). Sin embargo, la Historiografía tradicional del Occidente de México (especialmente en Jalisco y Zacatecas) considera que la minería, como una práctica sistemática para la extracción de minerales como el oro y la plata se dio gracias al "descubrimiento" de vetas por parte de los conquistadores españoles. ${ }^{21}$

De hecho, los españoles no pudieron explorar las zonas del Cañón de Tepeque y Zacatecas hasta que finalizó la guerra del Mixtón. En la zona de Tepeque los españoles comenzaron a explotar los yacimientos de plata y, para 1548 la población indígena se encontraban bajo la encomienda de Diego Fernández de Proaño y Hernando Martel. Sin embargo, los españoles fueron expulsados de la zona hacia la sexta década del siglo XVI. Mientras tanto, las minas de los Zacatecas fueron "descubiertas" por Juan de Tolosa, Diego de Ibarra y Cristóbal de Oñate en 1546.

$\mathrm{Al}$ resaltar el término de "descubrimiento", además de ignorarse la importancia de la minería prehispánica, se oculta el pequeño detalle de que fueron precisamente indígenas, oriundos de la región, quienes guiaron a los españoles hasta los yacimientos de Zacatecas. Para esta época, muchos caxcanes habían sido esclavizados y trabajaban en las minas para los encomenderos (Gerhard, 1996; Bakewell, 1976, 1990; Powell, 1996; Parry, 1993). ${ }^{22}$ Algunos de estos indígenas, que habían sido enviados a las minas de plata de Taxco y Sultepec pudieron huir a Zacatecas, y guiaron a los españoles a los depósitos de plata de esta zona (Powell, 1996: 239; Ruiz Medrano, 1994a; Carrillo Cázarez, 2000). ${ }^{23}$

Si bien, la fundación de los asentamientos mineros mencionados es posterior a 1542, consideramos dos posibilidades: la primera, que el interés de los conquistadores españoles haya sido uno de los motivos para registrar las zonas de interés minero desde los primeros años. La segunda: que el registro, relativamente impreciso de estas zonas, se haya realizado

\footnotetext{
21 Esta idea es reproducida por Bernabéu Albert y García Redondo (2010).

22 Parry señala este hecho en 1548 (Parry, 1993: 70).

23 Powell atribuye esta información a Gonzalo de las Casas en sus Noticias de los Chichimecas, mientras que Carrillo Cázares hace notar que esta obra en realidad fue redactada por Guillermo de Santa María, frayle agustino dedicado a la conversión de los chichimecas entre 1566 y 1575.
} 
una vez que el mapa estuviera en manos de Martínez de la Marcha debido a que la ubicación de estos asentamientos podía considerarse como un secreto de Estado (Hillerkuss, 2013).

A finales de 1549, en Zacatecas se habían asentado doscientos cincuenta españoles dedicados a la minería que iban sin familia, pero se hacían acompañar de esclavos indios y negros (Bakewell, 1976; Gerhard, 1996). En su carta de 1551, Martínez de la Marcha le describía como un campamento más que como un asentamiento formal, una comunidad pujante pero desorganizada cuyos envíos de plata eran constantemente atacados por los indios zacatecos, entre los que se había refugiado Tenamaxtli (Martínez de la Marcha, 2000; Carrillo Cázarez, 2000). Entre 1554 y 1572, la cifra de españoles aumentó a trescientos (y cincuenta más en Pánuco), además de mil quinientos indios y quinientos esclavos, cifras que fueron variando dependiendo de la prosperidad de las minas, las epidemias y otros factores (Gerhard, 1996). En la zona del Nayarit también se explotaron, en diferentes momentos, los reales de minas de Tenamanchi y Naguapan, además del beneficio de minas de Chimaltitlan (que aparece como Cuyuchimal en la Pintura) y Acuitapilco en la jurisdicción de Tequepespan (Gerhard, 1996).

En tanto, en la zona de Juchipila se formaron estancias ganaderas y asentamientos agrícolas que darían origen a las haciendas regionales, además de una importante ruta comercial que conectó a las ciudades de Guadalajara y Zacatecas ${ }^{24}$ (Chevalier, 1999; Gerhard, 1996). Esto hizo que, debido a su ubicación en una zona con una mayor densidad de población, su cercanía a otros pueblos españoles y a las principales rutas de abastecimiento y comercio de productos europeos, incluyendo el camino hacia la ciudad de México, además del impulso de la agricultura y la ganadería, en los años siguientes Guadalajara se convirtiera de hecho, en la principal ciudad de la Nueva Galicia (Carrillo Cázares, 2000; Parry, 1993).

Posteriormente se fundarían asentamientos como Santa María de los Lagos en 1563 y Jerez de la Frontera en 1570. La primera para proteger a los viajeros y comerciantes provenientes de Michoacán, así como la ruta de acceso entre Guadalajara y Zacatecas y la segunda para proteger las dos rutas que comunicaban la ciudad de Zacatecas con Guadalajara por el Suroeste. Otro aspecto ligado con este proceso fue la integración de los indígenas a las actividades comerciales a través de la arriería, convirtiéndose en los principales intermediarios entre Zacatecas y los asentamientos agrícolas de la Nueva Galicia y Michoacán para adquirir productos

24 Al igual que en Zacatecas, los españoles llegaron acompañados de criados indios y negros (Gerhard, 1996). 
como maíz, frijol, chile, algodón, calabaza y productos de maguey (Powell, 1996; Bakewell, 1976, 1990), lo que en algunos casos pudo representar la continuidad de las antiguas rutas de comercio regional.

\section{La importancia política de la Pintura del Nuevo Reino de Galicia}

Obviamente, cuando nos referimos a Guadalajara, se trata de su asentamiento definitivo, ${ }^{25}$ fundado en el Valle de Atemajac en 1542 (Tello, 1968, 1973; Weigand, 2015b) y que es representado como una traza urbana con cuatro manzanas (López Guzmán, 2008: 120), lo que es posible, o una ciudad europea, almenada y amurallada (Calvo y Machuca, 2016; Álvarez, $2009,2016)$ que no necesariamente existía. Esta representación es singular si consideramos dos aspectos: el primero, que Guadalajara parece una ciudad plenamente española en contraste con las zonas habitadas por los pueblos indígenas en pie de guerra. El segundo, que la capital de la Nueva Galicia era Compostela, mostrada como una concentración de tres casas de mayor tamaño que podrían identificarse como la supuesta edificación de su iglesia (López Guzmán, 2008: 120) o un "simple villorrio con techos de paja en los confines de la tierra" (Calvo y Machuca, 2016: 38).

Bernabéu Albert y García Redondo (2010), así como Álvarez (2009, 2016) plantean que la intención de Martínez de la Marcha al ordenar la elaboración de la Pintura, además de mostrar la geografía de la región, era demostrar la conveniencia de desplazar la capital de Compostela a Guadalajara, así como delimitar el territorio ocupado por los obispados de Michoacán y la Nueva Galicia, intereses también promovidos por Gómez de Maraver. Para fundamentar esta idea, podríamos considerar que, además de la descripción gráfica, el mapa cuenta con información complementaria sobre la jurisdicción política y religiosa de los puntos señalados en él al indicar al dorso del mapa que: "Todos los pueblos que tienen cruzes son de la governación de México. El liçençíado Hernando Martínez de la Marcha [alcalde mayor y visitador de Nueva Galicia que hizo información en 8 de enero de 1550]", además de que forma parte de las "Provanzas hechas por parte de la ciudad de Guadalajara y otros pueblos de Nueva Galicia en el pleito suscitado entre los obispos de la Nueva Galicia y Michoacán, sobre demarcación de sus límites y mudar la silla de la ciudad de Guadalajara a la de Compostela"26 (Páez Brotchie, 1957).

\begin{tabular}{l|l}
25 & Fundaciones previas se habían dado en Nochistlán, Tonalá y Tlacotán (Tello, 1968). \\
& Salvo Nochistlán y Tonalá, Tlacotán no aparece en la Pintura. \\
& Según el portal de Archivos Españoles, estas probanzas se encuentran bajo el título
\end{tabular} 
En este sentido, los pueblos marcados con una cruz corresponden a la Provincia de Ávalos ${ }^{27}$, sujeta a la Nueva España y el Obispado de Michoacán, pero que carecía de una frontera natural respecto a lo que Álvarez (2016) denomina el Altiplano Central Neogallego, como lo fue el Río Santiago respecto a las zonas Caxcana y Nayarita. Esto apuntaría a la posibilidad de que se planteara una fusión de este territorio a la Nueva Galicia y su obispado (Álvarez, 2009, 2016) y que generó la disputa entre los obispos Quiroga y Maraver.

Debido a su situación geográfica y la cercanía respecto a otros poblados españoles, es posible que el tlacuilo responsable de la elaboración de la Pintura, guiado por la persona que lo encargara (Maraver) apreciaran el potencial de Guadalajara, y por lo mismo crearan una imagen mental de lo que debía ser la ciudad aunque su entorno no correspondiera con la imagen que aparece en la Pintura. En su carta de 1544 al Rey de España, Gómez de Maraver proponía fortificar las ciudades y que fueran "muy grandes fosadas, munidas y pertrechadas, las cuales tengan sus guardias y alcaides, para que movido algún levantamiento o alboroto (...) se resista y ampare el ímpetu y fuerza de estos naturales" (2000: 474), imagen que en cierta medida concuerda con la idea de la ciudad europea, almenada y amurallada que vemos en la Pintura.

A la llegada de Martínez de la Marcha y sus colegas, este nuevo asentamiento, a pesar de sus limitaciones, debió contar con cierto nivel de desarrollo y enriquecimiento, favorecido por su situación estratégica para el flujo de plata y ganado rumbo a las zonas mineras, lo que contribuyó para que se postulara como nueva sede administrativa de la Audiencia de la Nueva Galicia y su obispado, meta conseguida hacia 1560 (Yañez, 2001; Enciso Contreras, 2016). Además Martínez de la Marcha contribuyó a este crecimiento al promover el mejoramiento de sus calles, la construcción de caminos de acceso, además de fomentar el comercio a través de la creación de tiendas en el centro de la ciudad y un mercado central para la población indígena (Román Gutiérrez, 2004; Bernabéu Albert y García Redondo, 2010).

Sumado a lo anterior, debemos considerar a la Pintura como un relato visual que refleja una demanda constante que se extendió del siglo XVI hasta el siglo XVIII: el sometimiento de los indígenas que se mantuvie-

de Informaciones y Probanzas. Guadalajara, bajo el Código de Referencia ES.41091. AGI/24.61.1//JUSTICIA, 1041.

27 Este correspondería al corredor lacustre intermontano, entre la Sierra de Tapalpa, El Tigre y las partes altas de las cuencas de los ríos Atoyac, Sayula y Tamazula (Álvarez, 2016). 
ran en pie de guerra, tal como lo hicieran Gómez de Maraver (Gómez de Maraver, 2000; Carrillo Cázares, 2000: 463 y 476), Martínez de la Marcha (2000), Arias y Saavedra $(1975,1986,1990)$ u Ortega $(1944,1996)$.

\section{Sobre la precisión geográfica}

Autores como Pizano y Saucedo (1964-1965), así como Calvo y Machuca (2016) y Álvarez (2016), señalan la falta de precisión geográfica de la Pintura del Nuevo Reino de Galicia debido a la carencia de conocimientos cartográficos de su autor. Esto se debe, en parte, a la falta de márgenes, pero también a la ausencia de elementos propios de la planimetría de la época, como la falta de escalas o referentes claros para su orientación (Bernabéu Albert y García Redondo, 2010). No obstante, se propone la idea de que su orientación tiene una perspectiva levantina, propia de un mediterráneo como lo era Martínez de la Marcha (Calvo y Machuca, 2016). De igual modo, se plantea que este mapa es una singular creación gráfica a partir de la visión de los habitantes de la Nueva Galicia, considerados como los protagonistas de la aparición de una nueva región histórica (Álvarez, 2016).

Desde esta perspectiva, pareciera que la historia del Occidente de México comienza a escribirse al momento en que se instaura la sociedad ibérica en un territorio aparentemente virgen. Las sociedades indígenas, consideradas como belicosas, brutales, son convertidas en pueblos sin historia (Wolf, 1987; Weigand y Romero de Solís, 2000), dignos de ser dominados. A diferencia de los autores citados previamente, consideramos la posibilidad de que este documento fuera realizado por un tlacuilo que participara en la Guerra del Mixtón y que obviamente, desconocería las convenciones cartográficas occidentales de la época, aunque empezaba a experimentar con la perspectiva occidental y elementos estilísticos introducidos por los misioneros, lo que contribuye a la singularidad de esta ilustración. Esto explicaría su fuerte influencia mesoamericana y, contrario a lo que opina Pizano y Saucedo (1964-1965), y Calvo y Machuca (2016), su precisión geográfica al contrastarlo con la cartografía contemporánea, aspecto considerado por Boehm (1995 e información personal), Weigand (2015b) y Weigand y García $(2000,2002 a)$.

Analizándola con mayor detenimiento encontramos que, en realidad, la Pintura combina dos perspectivas: tanto la mesoamericana como la occidental, al mismo tiempo que comprime el territorio de tal forma que se ajuste a la superficie que la soporta. Si nos guiamos por la orientación propuesta para su análisis (Oriente-Poniente, Norte-Sur), la ubicación de los pueblos del Pacífico es bastante precisa (Imagen 11). Sin embargo, 


\section{Imagen 11}

Diagrama de la Pintura del Nuevo Reino de Galicia desde una perspectiva Occidental

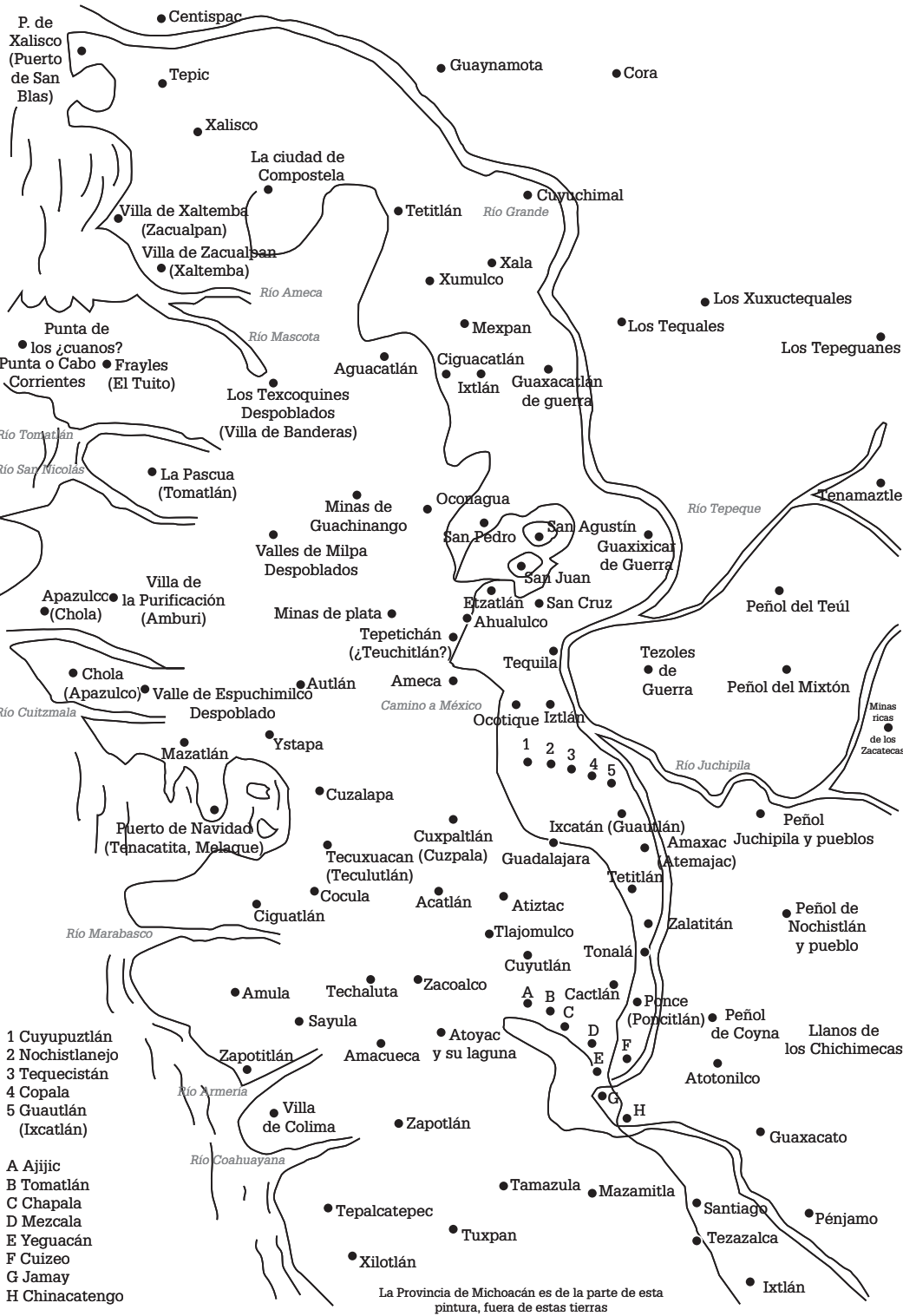

\section{Fuente:?}




\section{Imagen 12}

Elementos con orientación occidental en la PNRG

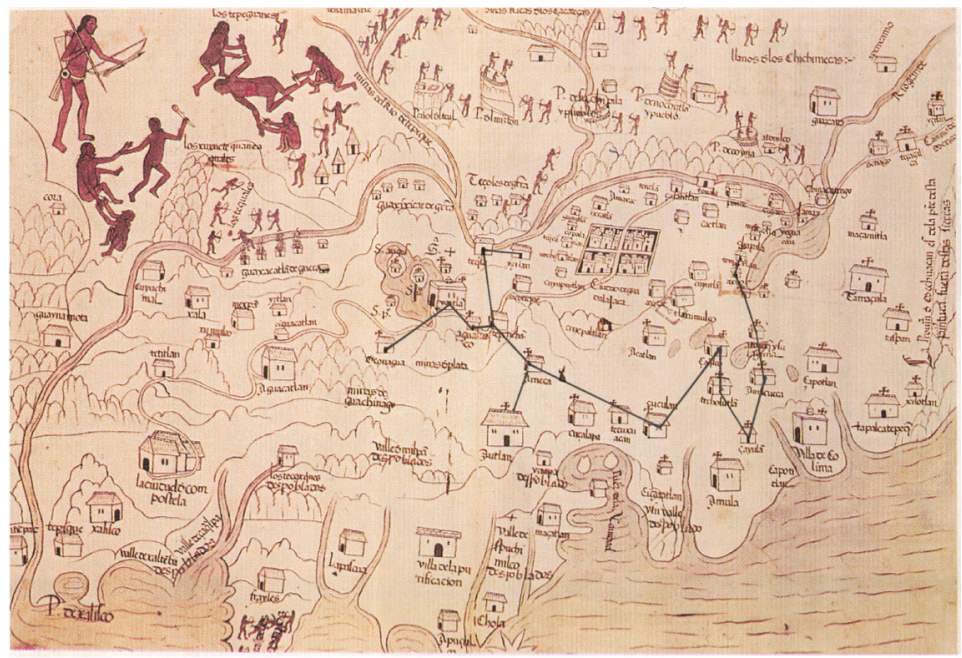

Fuente: Portal de Archivos Españoles. Ministerio de Educación, Cultura y Deporte del Gobierno de España.

las dimensiones del mapa y la cantidad de la información compactada en el mismo, pudieron incidir para cometer algunos errores. Sin embargo, su presencia podría dar la pauta para pensar que este documento es resultado de un experimento para crear un códice topográfico en un nuevo formato, el europeo, en una sola hoja de pequeñas dimensiones.

Entre los errores señalados se encuentran los siguientes: el Valle de Xaltemba ${ }^{28}$ y Zacualpan, Apazulco y Chola (en la zona del Océano Pacífico); así como Guautlán e Ixcatán, en las cercanías de Guadalajara, están invertidos. De igual modo, Ocotique debería encontrarse al norte de Tequila, por lo que no descartamos que el mapa fuera dibujado por un tlacuilo y que un escribano se encargara, posteriormente, de incluir los nombres de los asentamientos y las naciones indígenas lo que generaría algunas confusiones al registrarlos.

Mientras tanto, algunas zonas específicas tienen una orientación distinta al resto de la Pintura: Norte-Sur, Este-Oeste (1 Oconahua- Etzatlán-Ahualulco-Tepetichán-Tequila-Iztlán, 2 Cocula-Zacoalco-Techalutla-Sayula, Amacueca, Atoyac-Ajijic-Tomatlán-Chapala, ambos unidos por 3 Autlán-Ameca) (Imagen 12). Al parecer, esto sirvió para tener una pers-

${ }_{28} \mid$ Villa, según Acuña. 
pectiva adecuada que permitiera dar cierta relevancia a los cuerpos de agua comprendidos por la Provincia de Ávalos. En tanto, la zona Caxcana y Zacateca, enmarcada por los ríos Tepeque y Juchipila se comprimen de tal forma que se inclinan hacia el sur de su ubicación real. Es posible que esto se deba al peso que el tlacuilo dio a las imágenes del guerrero y las las escenas de sacrificio que sirven como marcador de este códice como relato visual.

En este sentido, aunque contiene algunos errores, juegos de perspectiva y compresión de elementos geográficos, la Pintura es bastante realista respecto a la localización de los ríos, lagos y asentamientos humanos. En cuanto a las cadenas montañosas y bosques, a simple vista parecen un caprichoso conjunto de detalles geográficos. Sin embargo, al realzar estos elementos con la metodología utilizada para el análisis de los códices mesoamericanos, y considerando una lectura del paisaje contrastada con la revisión de mapas topográficos y digitales, podemos apreciar que existe cierto realismo a partir de la observación desde puntos de vista específicos. De hecho, podríamos pensar que el documento es más preciso en algunos aspectos estratégicos, como el desarrollo de la ciudad de Guadalajara a partir de 1542, la cercanía con las sociedades indígenas en pie de guerra y el interés por controlar los caminos que permitirían el flujo de las mercancías y ganado, además de la prospección minera.

Ejemplo de una lectura equívoca o falsa orientación de este mapa es citada por Páez Brotchie en su definición de los límites del Obispado de Compostela, basada en la lectura occidental del mapa, que delata un aparente desconocimiento de la región, pues: "sólo alcanza hacia el poniente como límite del obispado por ese rumbo a Centipac y Huaynamota en la ribera derecha del Santiago" (Páez Brotchie, 1957: 157, también citado en: Orendain, 1961: 30 y Yáñez 2001: 82). Según la lectura sugerida en este trabajo, Centispac se encuentra al noroeste de la Pintura (extremo inferior izquierdo), mientras que Huaynamota se encuentra al norte, lo que concuerda con la cartografía actual ${ }^{29}$. Por otra parte, los datos aportados por Martínez de la Marcha en sus informes sobre la ubicación de los diferentes grupos étnicos, los nombres de sus caciques y las alianzas establecidas entre ellos, son bastante precisos y se reflejan, con mayor claridad, en el mapa de Ortelius (Téllez, 2010). gand 1992b, 1993a; Weigand y García 1996, 2000a, 2002a) y Téllez (2005), han leído este documento conforme a la perspectiva de la cartografía Occidental 


\section{Los grupos étnicos, la guerra y los sacrificios humanos} en la Pintura del Nuevo Reino de Galicia

Aunque Neurath $(1998,2002)$ la considera como una fuente etnográfica poco confiable, sus imágenes concuerdan con las descripciones proporcionadas por las crónicas recopiladas por Razo Zaragoza (2001) y Tello en su Crónica miscelánea (Tello, 1968, 1973), las cuales contienen suficientes detalles geográficos y demográficos sobre los Estados Caxcanes y Transtarascos, además de la existencia de los asentamientos y sitios defensivos que, al igual que los de la Pintura, pueden ser corroborados por medio de las técnicas de la arqueología de campo, propuestas por Armillas (1987) y aplicadas por Hers $(1989,1992,2010)$ Weigand (1993) y Weigand y García (1996). Además, ofrece una de las primeras definiciones de los grupos étnicos del Occidente de México, especialmente en lo que se refiere a las zonas Caxcana y Nayarita. Así entre los ríos Santiago y Tepeque podemos ubicar, de manera general, a los Coras, Guaynamotecos, los Xuxuctequanes, los Tequales, los Tepeguanes y los Tepecanos. También tenemos a los Caxcanes (identificables por los hechos bélicos en los peñoles, pero también por el nombre de Tenamaztle), los Zacatecos, los Chichimecas y los Tezoles. Respecto a los pueblos de la zona Transtarasca que aún se mantenían en armas, ubicamos a Guajacatlan y Guaxixicar identificados por Tello (1968) como Cuanos, liderados por Guaxicar, señor de Xochitepec ${ }^{30}$ (Weigand, 2013, 2015; Weigand y García, 1996, 2000, 2002a).

La Zona Nayarita se encuentra en la esquina superior izquierda, entre los ríos Tepeque (Bolaños), al sur y el Grande de Santiago al poniente ${ }^{31}$ (Imagen 13). En el extremo norte destaca la presencia de las población de Cora y, al oeste de la misma, Guaynamota. Puede que Cora corresponda a Tzacaimuta o la Mesa del Nayar, sede del adoratorio del Sol, uno de los más importantes de la zona Nayarita y que mantenía constantes guerras con los Huaynamotecos (Arias y Saavedra 1975, 1986, 1990; Santoscoy, 1986). Al oriente de esta zona se encuentran los Tepeguanes y hacia el oeste se encuentran los Tequales o Tecuales, que, al parecer, se ven enfrentados a los de Guaxacatlan o Guaxacate, ubicados al oeste del río Santiago, en la zona Transtarasca. En medio de la zona Nayarita se encuentran los Xuxuctequanes. Al parecer, debió cometerse un error al escribirse el término Xuxuctequanes, ya que se puede apreciar una pequeña corrección. La palabra había sido escrita en dos líneas: Xuxucte/ quales, pero la segunda partícula fue cruzada por una raya y, posterior-

\footnotetext{
30 Al parecer esta zona corresponde a la de Etzatlán-Guaxacate (Magdalena)

31 Al noreste, según la lectura propuesta.
} 


\section{Imagen 12}

Detalle de la Zona Nayarita en la PNRG

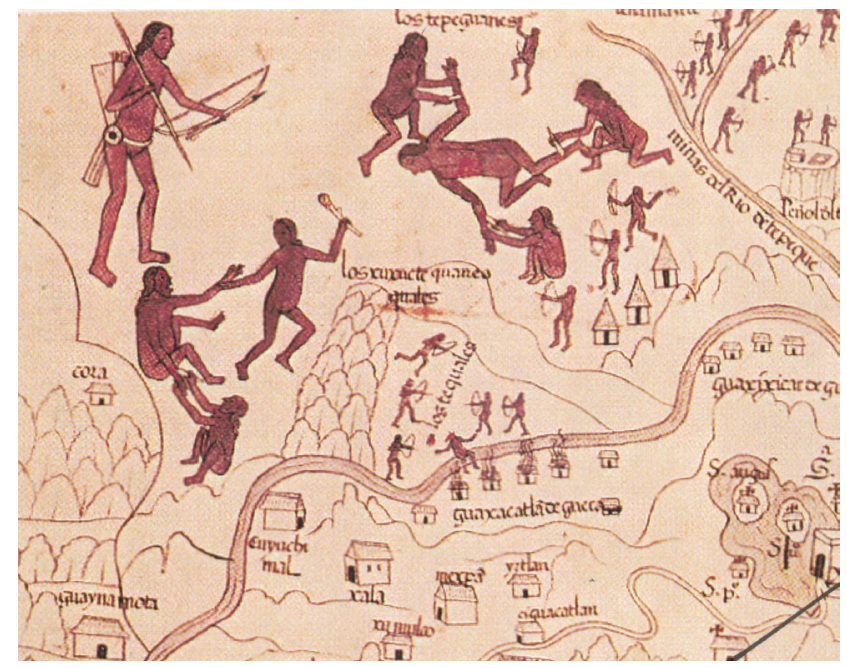

Fuente: Portal de Archivos Españoles. Ministerio de Educación, Cultura y Deporte del Gobierno de España.

mente se agregó la partícula quanes (coanos). Esta corrección se hace evidente por el tamaño de las letras utilizadas en ambas terminaciones. El tipo de letra utilizada en la partícula es del mismo tamaño que en Xuxucte, pero en quanes es de un tamaño un poco menor.

¿Cómo podemos interpretar este aparente error del autor del mapa? Es seguro que esta zona incluyera a los ancestros de Huicholes, quienes a su vez, estaban emparentados lingüísticamente a los Tequales, como lo señalara Arias y Saavedra en 1673 (1975, 1986, 1990). Sin embargo, en el aspecto político y ceremonial los Tequales tenían mayor cercanía con los Coras, como lo hicieron notar tanto Arias y Saavedra como los jesuitas Lauria, Doye, Abarca y Ortega lo largo del siglo XVII (Meyer, 1989; Ortega, 1944, 1996). Cabe la posibilidad de que se hubieran apreciado ciertos rasgos culturales y lingüísticos, además de alianzas o relaciones políticas que permitieran relacionar a los Xurutes y los quanes, lo que derivaría en su caracterización como Xucuctequanes, distinguiéndolos claramente de los Tequales. ${ }^{32}$ Un elemento particular de esta zona es la existencia

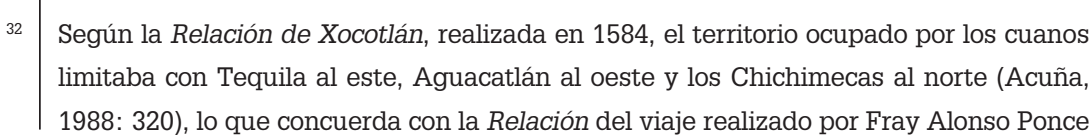


de tres recintos circulares, con techo cónico de paja, muy parecidos a las estructuras ceremoniales (Tukite) de los Wixaritari (huicholes) contemporáneos, aunque hay uno más en la zona caxcana, cerca de las "minas ricas de los Zacatecas".

En la esquina superior derecha de la Pintura, rodeada por el Río Grande y el Río de Tepeque ${ }^{33}$ se aprecia la zona Caxcana. En esta sección sobresalen las escenas bélicas, protagonizadas por contingentes indígenas que se encuentran en pie de guerra, armados principalmente de arcos y flechas y, en menor medida, mazas o porras; además de los sitios defensivos similares a los descritos por Hers $(1989,1992)$. Así, resalta el asedio a los peñoles o fortificaciones de Nochistlán y su pueblo, Juchipila y sus pueblos, el Mizton (Mixtón) y el Teúl, sede del liderazgo pancaxcano; así como los Teçoles de guerra, ubicados en el margen oriental del Río Santiago, entre los ríos de Tepeque y Juchipila. Aunque fuera de la zona Caxcana, también puede apreciarse el Peñol de Coyna.

\section{Las fortificaciones indígenas en la Pintura}

Estos peñoles, especialmente los de la zona Caxcana, corresponden a un tipo de asentamientos defensivos ubicados en lo alto de mesetas con estrechos accesos, protegidos por barricadas de piedra, cuyo objetivo era mantener el control sobre un territorio y sus rutas de comercio, brindar protección a los no combatientes, así como ayudar a los defensores en su retirada (Armillas, 1991; Lameiras, 1994). Armillas consideraba, hacia 1951, que este tipo de asentamiento prevaleció a principios del si-

\footnotetext{
(Ramírez Flores, 1968; Ciudad Real, 1976), que los ubicaba en las laderas de serranía al norte de Xala, extendiéndose hasta el Río Grande de Toluca (Santiago). Esta última indica que la lengua Pinutl, Pinome o Pininuquia, era la misma que hablaban coras, cuanos huaynamotecas, así como algunos pueblos de Centispac, en la costa de Nayarit. Derivado de esta información, hay un acuerdo respecto a que la lengua de los coanos formaba parte de la familia uto-azteca, específicamente del grupo cora-chol. Aunque Harvey pensaba que era una lengua indeterminada (1972, Acuña, 1988), algunos autores sugieren que esta lengua podría identificarse como una variante de la lengua cora (Sauer, 1932; Kroeber, 1934; Dávila Garibi, 1939; Gerhard, 1996; Acuña, 1988: 317; Cifuentes, 1998). Debe considerarse que Guaynamota era un punto de confluencia entre Coras, Tecuales y Huicholes, por lo que cabe pensar si la lengua de los Cuanos fuera una variante del Tecual-huichol o que los constantes cambios entre los siglos XVI y XVII reconfiguraron la densidad de población y su configuración étnica si consideramos la descripción hecha por Arias y Saavedra $(1986,1990)$.

33 Al sureste del Río Tepeque, según la lectura propuesta.
} 
Imagen 14

Plano de El Teúl realizado

por De Bergues en 1834

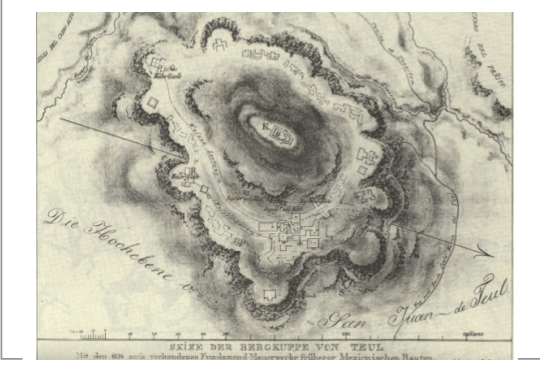

Fuente: Tomado de Weigand y García (1996, p. 172).
Imagen 15

Cerro del Teúl

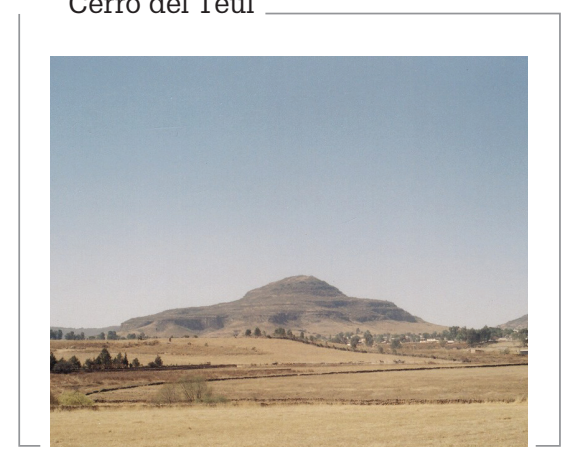

Fuente: Foto de Víctor Manuel

Téllez Lozano.

glo XVI, aunque trabajos arqueológicos posteriores han demostrado que existieron fases ocupacionales en diferentes épocas (Medrano Enríquez, 2001, 2012, 2014). Además del carácter estratégico de estos asentamientos, que permitía la defensa ante un asedio, algunos de estos (como el Teúl) eran centros de organización política y ceremonial, donde se concentraban templos, palacios, juegos de pelota, cuarteles, arsenales, etc. (Weigand y García, 1996), aunque otros, como el Mixtón o el de Juchipila podían contar con una arquitectura menos compleja (Weigand, 2015b).

Sobre el Peñol de Coyna, Armillas considera que en la zona del Bajo Lerma y el Valle del Río Santiago, estas fortificaciones se reducían a montículos rocosos, fortificados de forma precipitada con terraplenes de piedra cuando era necesario (Armillas, 1991). Al parecer, el peñol de Coyna (Tototlán) podría encontrarse en el cerro de Proaño, en la zona limítrofe entre Tototlán y Atotonilco el Alto. De hecho, Fernández y Deraga (s/f) localizaron en este sitio estructuras complejas que incluyen cuatro montículos que limitan plazas cuadrangulares con acceso a las esquinas.

En este sentido, el peñol del Teúl, ilustrado por primera vez por De Berges, en 1834 (Imagen 14 y 15), era descrito como un complejo arquitectónico de gran importancia que "muestra ser cosa de mucha grandesa y abtoridad, porque lo mas hera de edificios y ques, muy suntuoso, que cada uno de los señores de la provincia devia tener allí para ir hacer sus sacrificios" (Carta a S. M. de [...] Nuño de Guzmán, 8 de julio de 1530, De Guzmán, 2001: 47; también citada en Parry, 1993, P: 63 ).

A lo largo de la obra de Tello se le describe como un asentamiento fortificado en un cerro compuesto por una mesa donde se encontraba el asentamiento principal, rodeado por una peña tajada con una entrada de 
Imagen 16

Cerro del Tuiche o Peñol de

Nochistlán

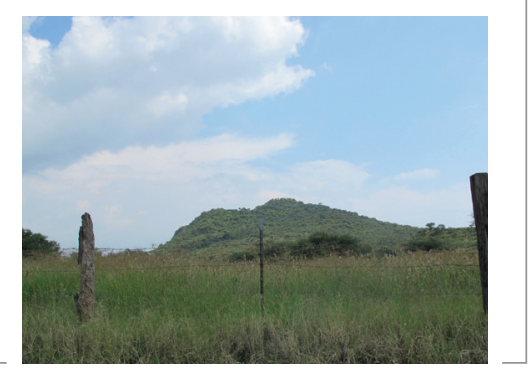

Fuente: Foto de Víctor Manuel Téllez Lozano. (1996, p. 172).

\section{Imagen 17}

Cerro del Tuiche o Peñol de

Nochistlán

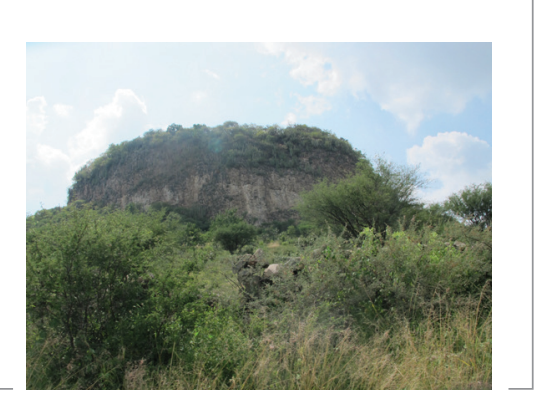

Fuente: Tomado de Weigand y García (1996, p. 172).

grandes escalones y una fuente de agua labrada en piedra, además de un templo. Sobre esta mesa, había un cerro redondo. Hacia 1531 tenía una población de unos seis mil habitantes, aunque se indica que podrían caber veinte mil personas (Tello, 1968). Según las crónicas, el Templo del Teúl era el principal centro de adoración regional, pero su poder político se hace evidente si consideramos su autoridad sobre la zona Caxcana (Tello, 1968; Weigand y García 1996).

Dicha jerarquización se apreciaba en Juchipila, donde habían edificado su propio templo sujeto al del Teúl. Este se encontraba en su Toch o peñolete entre Juchipila y Apozolco (en el Cerro de las Ventanas), donde se había erigido una albarrada para impedir el paso de los españoles (Tello, 1968: 125, Weigand, 2015b). A esto podemos sumar el testimonio de Fernando Sandoval Acazitli (citado en Ruiz Medrano 1994a: 373), que indicaba la existencia de un templo y sofisticadas construcciones en la cumbre del Peñol, información corroborada por Mozillo, quien indica una larga secuencia de desarrollo (s/f, citada por Weigand y García 1996: 105). Por su parte, el Peñol de Nochistlán, se describe como un peñol fortísimo, rodeado de agua y que contaba con su propio templo ${ }^{34}$ (Tello, 1968: 27, 125). Trabajos recientes (Medrano Enríquez, 2012, 2014) han situado este peñol en el cerro del Tuiche, identificado como el principal centro político-ceremonial de Nochistlán, cuyas terrazas sirvieron como elemento defensivo para los habitantes del peñol y los refugiados provenientes de sus barrios y de los ranchos aledaños ante el avance de los españoles (Imagen 16 y 17).

${ }_{34}$ Según esta descripción, hacia 1531 tendría unos seis mil habitantes. 
En la Pintura, los peñoles son dibujados con una forma casi cilíndrica y, en el caso de el Teúl, el Mixtón, Juchipila y Coyna, rematados por una mesa o superficie plana, como una forma de convención para mostrar a los empeñolados en posición defensiva, aunque cada uno cuenta con ciertas particularidades. El peñol del Teúl aparece rodeado por una especie cerro o serranía cercana al río Tepeque, misma que parece ser escalada por un par de indios flecheros. En tanto, la cima aparece defendida por dos personajes con las mismas características, pero puede apreciarse una construcción de tipo habitacional y una estructura rectangular a nivel de piso, aspectos que podrían darnos a entender el templo y la fuente de agua descrita por Tello (1968).

El Mixtón es representado por otra elevación que muestra una especie de rampa en su base y una serie de peñascos en su parte media, rematado por un muro piedras que brinda refugio a cuatro guerreros. El de Juchipila es una estructura relativamente más baja y ancha, rodeada por lo que podemos entender como una zona boscosa y el río Juchipila, además de dos muros que sirven para dificultar el acceso y facilitar la defensa, realizada en este caso, por dos arqueros. De igual modo, el peñol de Coyna aparece flanqueado por un conjunto de cerros y una zona de bosque, mientras que el peñol cuenta, al igual que el de Juchipila, con dos muros de piedra que resguardan a cuatro personajes.

Mención aparte merece el Peñol de Nochistlán debido a su figura. Este peñol también tiene una forma cilíndrica, pero esta vez rematada por una serie de elevaciones o riscos, además de que se encuentra flanqueado por un abrupto acantilado, además de contar con cuatro refuerzos de piedra que podrían representar parte de las siete albarradas que enfrentaron los españoles (Tello, 1973; Medrano Enríquez, 2012, 2014).

La Pintura del Nuevo Reino de Galicia representa un hecho significativo en la historia de la región: en 1542, después de una espectacular campaña militar que culminó con la derrota de los Caxcanes en el Peñol del Mixtón, los españoles lograron sofocar la fase caxcana de la rebelión. Esto ocasionó el repliegue de las tropas Caxcanas, lideradas por Tenamaztle (Tenamaxtli) ${ }^{35}$, hacia la serranía de Tepeque, (Tello, 1973; Martínez de la Marcha, 2000; Carrillo Cázares, Vol. I, 2000; Weigand, 1992; Weigand y García, 1996, 2000, 2002a; Gerhard, 1996). Este hecho es representado con el nombre de Tenamaztle, acompañado de un grupo de indios flecheros

\footnotetext{
35 Tenamaxtli, hermano del señor de Nochistlán, junto a Petácal, señor de Xalpa, Xiuhtecuhtli, señor de Juchipila, y Tenquitatl (señor de un barrio de Juchipila), fue uno de los líderes Caxcanos más importantes durante la Rebelión de Nueva Galicia (Ruiz Medrano, 1994a y 1994b; Weigand y García, 1996; Yáñez, 2001; León Portilla, 1995).
} 
que aparentemente se dirigen hacia los Tepeguanes, específicamente en el delta donde convergen los ríos Mezquitic y Colotlán para unirse en el caudal del río Bolaños, señalado por la leyenda minas del río de Tepeque, área que correspondería geográficamente con la actual zona de Fresnillo y Jeréz y que era ocupada por indios Zacatecos y Guachichiles (Gerhard, 1996).

En la parte norte de lo que Weigand denomina como la zona Transtarasca, se aprecian los puntos señalados como Guaxacatlan de guerra y Guaxixicar de guerra, encabezados por Guaxicar, en el área ubicada al oeste del Río Grande y su confluencia con el río Tepeque, que además rodeaba la extinta laguna de Magdalena hacia el norte y el oriente (Tello, 1968; Weigand, 1993, 2013, 2015b; Weigand y García, 1996). La zona de Guaxacatlán se caracteriza por cuatro casas arrasadas por las llamas al poniente del río Grande de Santiago y las escenas de guerra contra los tecuales, que incluyen a un decapitado, en el margen oriental del mismo.

\section{Sacrificios humanos}

Evidentemente, todos estos grupos eran considerados como indios de guerra que, en el momento en que Martínez de la Marcha realizaba una de sus cartas, fechada en $1551^{36}$, seguían representando un peligro para los asentamientos españoles y los poblados indígenas sometidos a la Corona, acusándolos de "sodomía, idolatría y carnicería de carne humana que comen" además de negarse a someterse a la Corona española (Carrillo Cázares, 2000, Vol. II: 481). Esto da la pauta para considerar la importancia de las guerras floridas, los sacrificios humanos y el canibalismo ritual que caracterizaron a las sociedades mesoamericanas y que perduraron en la zona Nayarita, por lo menos, hasta la segunda década del siglo XVIII.

De hecho, una imagen predominante en este mapa tiene que ver con la representación de sacrificios humanos en los que manos, pies y corazón de las víctimas son desollados o arrancados. Retomando el extremo superior izquierdo de la Pintura, en este ángulo se encuentra un personaje indígena, semidesnudo, armado con carcaj a la espalda, arco y flechas en su mano izquierda, además de una lanza o jabalina en la mano dere$\mathrm{cha}^{37}$. Junto a este se encuentran las dos escenas de los sacrificios huma-

${ }_{36} \begin{aligned} & \text { AGI, Audiencia de Guadalajara 5: "Carta del Lic. de la Marcha } 18 \text { de feb. De 1551", } \\ & \text { íntegra en: Carrillo Cázares (2000, Vol. II: 479-487) } \\ & \text { Bernabéu Albert y García Redondo proponen que este personaje representa a Guaxi- } \\ & \text { car, a quien ubican como "líder de la resistencia del Nayarit y de las tierras altas de } \\ & \text { Xalisco" (2010: 168). Como se mencionó previamente, Guaxicar era cacique de Xochi- } \\ & \text { tepec y ejercía su dominio sobre los cuanos. Después de 1542, junto a sus tropas pudo }\end{aligned}$ 
nos que, por su tamaño, caracterizan a la Pintura. Si bien para Álvarez (2009, 2016) y Bernabéu Albert y García Redondo (2010) estas imágenes corresponden a los tepeguanes, en realidad estas prácticas eran características de las diferentes sociedades indígenas de las zonas Nayarita, Caxcana, Zacateca y Cuana, al igual que para los tepehuanes, y las vemos reflejadas en el sacrificio de animales en los mitotes ligados al culto solar: neixa para los huicholes, xuravet entre los mexicaneros o xiotahl para los tepehuanos (Preuss, 1998, Neurath, 1998, 2002).

De estas, una se encuentra al norte de esta zona, muy cerca de las poblaciones denominadas como Cora y Huaynamota. En esta imagen, apreciamos tres personajes completamente desnudos. La víctima se encuentra sentada, con un rictus de dolor en un rostro ensangrentado, mientras que uno de sus victimarios le detiene la mano izquierda, listo para liquidarlo con una maza, mientras que otro personaje sentado parece desollar o realizar un corte en la muñeca derecha. La segunda imagen, ubicada entre la zona de los Tepehuanes y los Xuxuctequanes, muestra a otra víctima del sacrificio con el dorso sangrante, como si le hubieran extraído el corazón, que está siendo desollado por otros tres personajes.

Mientras tanto, en la zona costera, hay una lectura dudosa, muy cercana al asentamiento de Frayles (El Tuito). Acuña (1988) propone tentativamente el nombre de Punta de los Coanos, aunque la lectura se hace difícil debido a que los caracteres latinos se confunden con las imágenes de los indios flecheros. Por su parte, Bernabéu Albert y García Redondo (2010), proponen el término Teconios. Una posibilidad que planteamos, es que se trate de una abreviatura del término coronados, utilizado para describir a los indígenas de la zona debido a su peculiar apariencia. ${ }^{38}$ Esta zona incluye un enfrentamiento entre dos bandos de indios flecheros (tres al norte y cuatro al sur) que enmarcan una escena de sacrificio humano o toma de prisionero en su parte oriental. En esta, el vencedor ha dejado

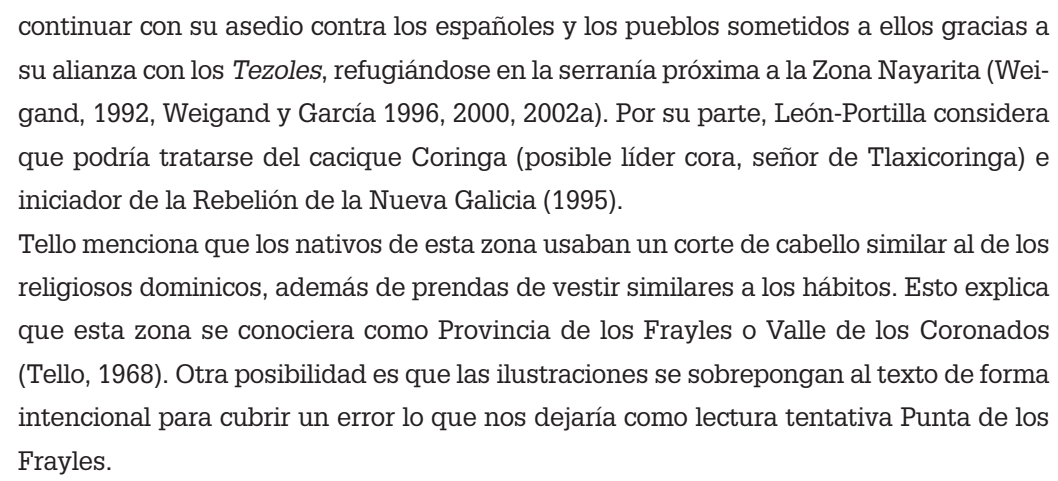


arco y flecha a sus pies mientras toma al vencido por los cabellos, imagen común en la representación de la toma de prisioneros en los códices. Tomando en cuenta la ubicación de esta escena, es posible que se trate de Punta o Cabo Corrientes y que haga referencia a los enfrentamientos entre los grupos étnicos de la región. La Relación de la Villa de Purificación (Acuña, 1988), nos indica que los pueblos de Malabaco, Cabrayel y Tomatlán forjaban alianzas para enfrentarse a pueblos cercanos, particularmente con Piloto, al norte de Malabaco y sur de Frayles.

Estas ilustraciones corresponden con las descripciones realizadas por Powell (1996) a partir del testimonio atribuido a Gonzálo de las Casas ${ }^{39}$. Según esta crónica, los chichimecas de Querétaro, más cercanos a los pueblos sedentarios del sur, abrían el pecho de las víctimas y sacaban el corazón latente. También arrancaban el cuero cabelludo mientras la víctima aún tenía vida, colocando un pie sobre su cuello y tirando contra la dirección natural del crecimiento del pelo. Asimismo arrancaban partes del cuerpo, como costillas y huesos de los brazos y piernas. Cualquiera de estos elementos era conservado como trofeo. Algunos prisioneros eran sometidos al cautiverio antes de sacrificarlos en los mitotes, donde realizaban danzas alrededor de la víctima ${ }^{40}$ (Powell, 1996).

De hecho, imágenes muy similares fueron ubicados por Hers en un petroglifo en la barranca del río Chapalagana, cercana al cerro del Huistle (2008: 25; 2010: 237) (Ver Imagen 9), además de que se ha encontrado evidencia de estas prácticas en un entierro múltiple del Postclásico tardío analizado por Medrano Enríquez en el sitio arqueológico de las Ventanas en Juchipila, uno de los más extensos en el estado de Zacatecas (Medrano Enríquez, 2001, 2014).

\section{Códices relacionados con la Guerra del Mixtón:}

Las campañas de conquista del Occidente de México, así como Guerra del Mixtón fueron hechos de singular importancia para los indígenas del Centro de México que participaron en estas campañas y trataron de mos-

\footnotetext{
39 Ver nota 20.

40 Según Powell, ocasionalmente cortaban lo genitales y los metían en la boca de la víctima. También practicaban el empalamiento. Algunas víctimas eran arrojadas por los despeñaderos y otras eran colgadas. También abrían las espaldas y les sacaban los tendones, que utilizaban para amarrar las puntas de flecha a las cañas. A los infantes los tomaban por los pies y les estrellaban la cabeza contra las rocas (Powell, 1996). A los ojos de los misioneros, esto es una muestra de crueldad que el demonio o las malas costumbres les han mostrado para matar con placer. Tal vez pudo acentuarse ante el proceso de conquista.
} 
trar su méritos ante la Corona española, como los tlalmanalcas, tlaxcaltecas, huejotzincas, tlatelolcas, xochimilcas, acolhuas, texcocanos, etc, pero también purépechas. (Ruiz Medrano, 1994a; Bernabéu Albert y García Redondo, 2010). La Descripción de la ciudad y provincia de Tlaxcala, realizada entre 1581 y 1584 por Muñoz Camargo, menciona la participación Tlaxcalteca en la conquista de Tenochtitlan, además de diferentes regiones que incluyen el Occidente de México y Centroamérica. De hecho, se hace referencia al alzamiento de Tenamaxtli y la muerte de Pedro de Alvarado (Muñoz Camargo, 2000). Las ilustraciones que acompañan esta Descripción son muy similares a las de el Lienzo de Tlaxcala, ${ }^{41}$ del cual se han consultado las copias realizadas en 1773 por José Manuel Yllañes, dividida en cuatro lienzos ${ }^{42}$ (lienzo número 3 ) y la de Chavero (de la Torre, 1983). Cada escena incluida tanto en la Descripción de Muñoz Camargo (2000) como en las copias mencionadas, muestra información importante en cuanto a la identificación de los pueblos conquistados, armamento, vestuario y tácticas de guerra y donde resaltan las ilustraciones referentes a Tototlán, Tonalá, Ixcatán o Juchipila.

En la mayoría de las ilustraciones se aprecia, en primer plano al lado izquierdo a los conquistadores españoles, generalmente a caballo, acompañados por las tropas tlaxcaltecas ricamente ataviadas enfrentando a los indígenas de los pueblos mencionados que se encuentran guarecidos en cerros, desde donde atacan con arcos y flechas, aunque también se aprecia el uso de macahuitl, mazas y escudos. En el caso de Tototlán y Juchipila se aprecia mejor la importancia de los peñoles como táctica defensiva. Estos son fácilmente identificables porque los indígenas se encuentran protegidos por muros de piedra alineados caracterizados por el glifo Tetl (piedra). Además, cada sitio es caracterizado por un toponímico que se encuentre en la parte superior de cada cerro: un ave (tototl) para Tototlán, un niño (pilli) y una flor (xochitl) para Juchipila (Imágenes 18 y 19$)$.

Otros códices, reproducen hechos específicos: por ejemplo, el Códice Tlatelolco, también conocido como Manuscrito de Xochipila, fue elaborado cerca de $1562^{43}$ por orden de don Diego de Mendoza Imauhyantzin.

41 Se ha discutido a posibilidad de que la versión original del Lienzo Tlaxcala se realizara cerca de 1552.

42

43 (

Esta versión del Lienzo de Tlaxcala se encuentra resguardada en la Biblioteca Nacional de Antropología e Historia.

Es preciso notar que a pesar de la cercanía temporal entre estos documentos, existen importantes variaciones estilísticas dependiendo del nivel de aculturación de cada uno de los tlacuilos que intervinieron en su realización. 
Imagen 18

Peñol de Tototlán

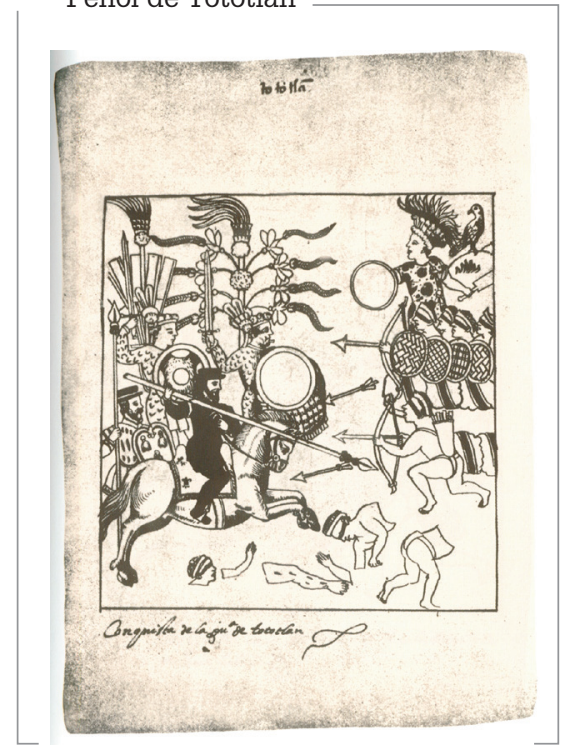

Fuente: Tomado de la Descripción de la ciudad y provincia de Tlaxcala, Cuadro 81 (en el Lienzo Tlaxcala, lámina 54, en Muñoz Camargo, 2000).

\section{Imagen 19}

Peñol de Juchipila

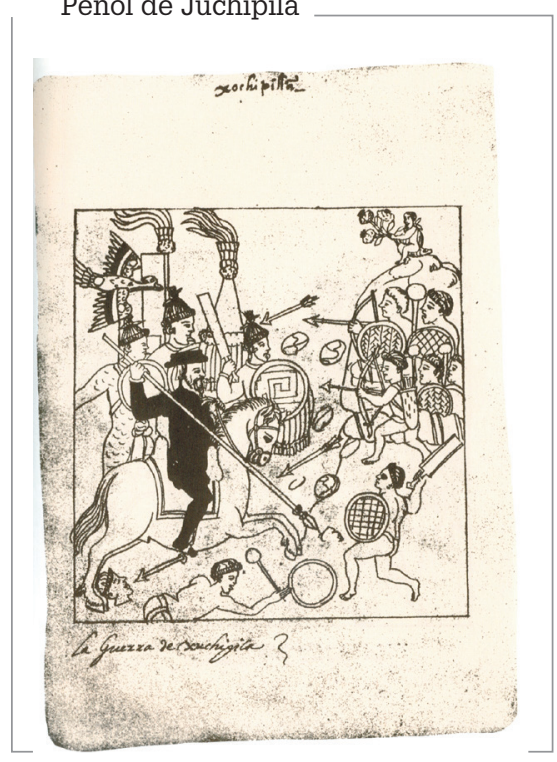

Fuente: Tomado de Descripción de la ciudad y provincia de Tlaxcala, Cuadro 85 (en el Lienzo Tlaxcala, lámina 58, en Muñoz Camargo, 2000).

Este muestra hechos sucedidos entre 1542 y 1560, así como la participación de los gobernadores de Tlatelolco Alonso Cuauhnochtli (1538-1540) en la campaña encabezada por Francisco Vázquez de Coronado hacia Culhuacan (Culiacán) y de don Martín Quauhtzin (1542-1548), en la batalla de Nochistlán (Valle, 2010; Pérez Rocha, 2012). Estos personajes usan un vestuario que mezcla la ropa indígena y europea, además de portar espadas. Erróneamente, Nochistlán es identificado por León-Portilla (1995) como Juchipila, debido a la presencia de un rostro bajo el cerro coronado por un nopal con tunas (1995). Sin embargo, en el glifo de Culhuacán aparece un rostro similar (Imagen 20).

La batalla de Nochistlán también se encuentra reproducida en los códices Telleriano-Remensis, realizado entre 1562-1563 (Hamy, 1899) y el Códice Ríos (Vaticano A-3738), realizado cerca de 1566. El Telleriano-Remensis incluye la salida de Nuño de Guzmán hacia Jalisco en 1529 (Folio 44r), así como la batalla en el Peñol de Nochistlán y la muerte de Pedro de Alvarado en 1541 (Folio 46r), (Imagen 21) hecho reproducido en el Folio 


\section{Imagen 20}

Códice Tlatelolco o Manuscrito de Xochipila

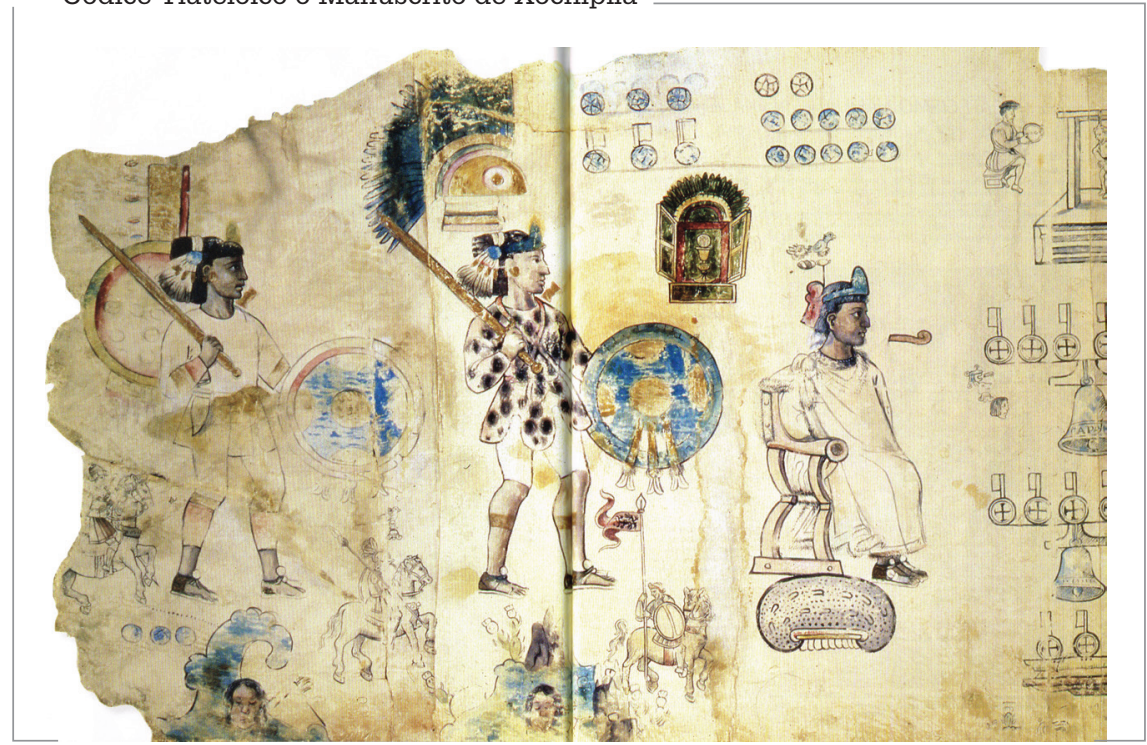

Fuente: Foto de Víctor Manuel Téllez Lozano.(1996, p. 172).

\section{Imagen 21}

Códice Telleriano-Remensis (Folio 46r). Batalla de Nochistlán
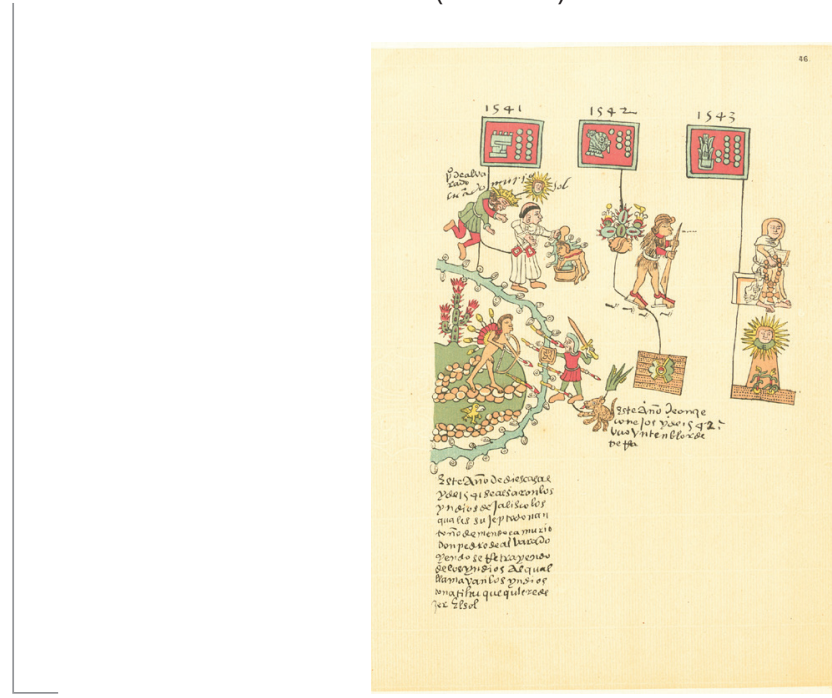

Fuente: Tomado de la página de la Fundacion para el Avance de los Estudios Mesoamericanos (FAMSI). 


\section{Imagen 22}

Códice Ríos Vaticano (Folio 93R).

Batalla de Nochistlán

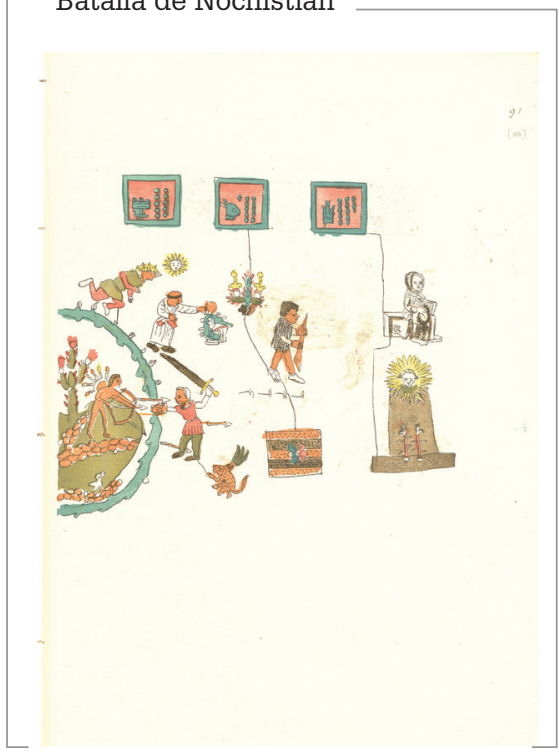

Fuente: Tomado de la página Pueblos originarios. Escritura y simbología.

\section{Imagen 23}

Códice Ríos Vaticano (Folio 54V)

Escena de sacrificio

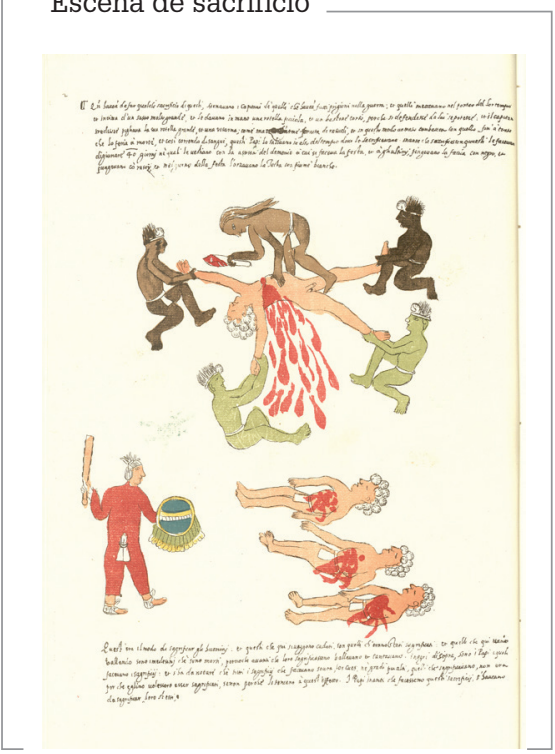

Fuente: Tomado de la página Pueblos originarios. Escritura y simbología.

93R del Códice Ríos (Vaticano A-3738)44 (Imagen 22). En este último códice, Folio 54V, hay una escena de sacrificio humano muy similar, pero más "realista" que la de la Pintura del Nuevo Reino de Galicia y el petroglifo del Chapalagana (Imagen 23).

Otra referencia a la Guerra del Mixtón se encuentra en el Códice Aubin o Historia de la Nación Mexicana, realizado en $1576^{45}$ (León Portilla, 1995; Fernández Díaz, 2014). Este códice representa en su folio 47 el glifo calendárico diez casa, que corresponde a 1541, y que muestra a un guerrero ataviado con penacho y armado de macahuitl y chimalli o rodela, asediando un cerro defendido por un indio flechero desnudo, protegido por una rodela. Esta escena es acompañada por la leyenda Nican

\footnotetext{
44 El códice Telleriano-Remensis se encuentra disponible para su consulta en la página de la Fundacion para el Avance de los Estudios Mesoamericanos (FAMSI). Por su parte, el Códice Ríos (Vaticano A-3738) se encuentra en la página de Pueblos originarios. Escritura y simbología.

45 El Códice Aubin se encuentra disponible en la página del Museo Británico.
} 


\section{Imagen 24}

Códice Aubin de 1576 o Historia de la Nación mexicana (Folio 47)

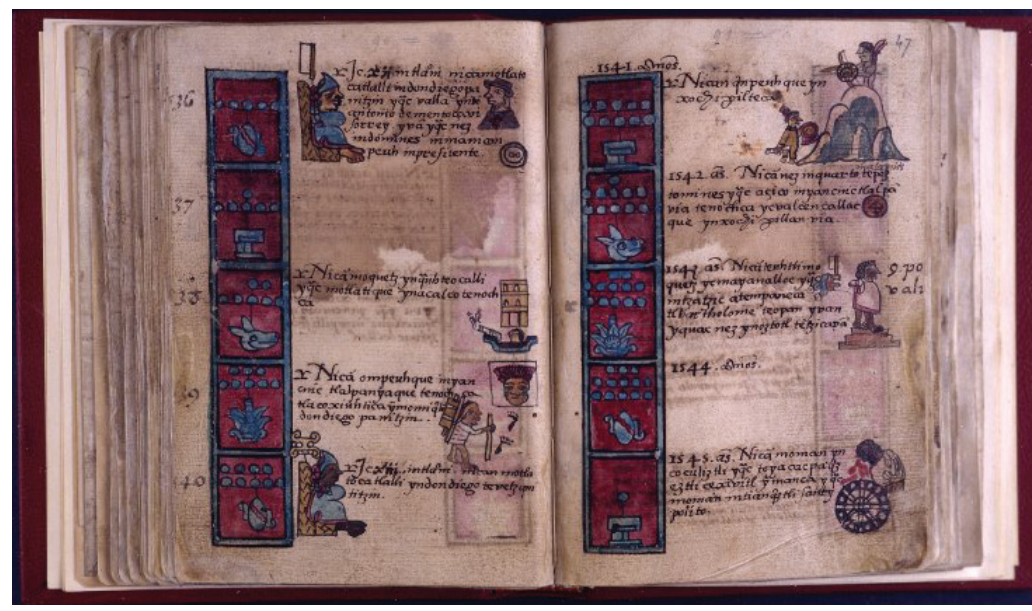

Fuente: Tomado de la página del Museo Británico.

anpeuhque yn Xochipilteca (Aquí perecieron los xuxhipiltecas) (Imagen 24) (León Portilla, 1995).

Otros códices importantes fueron realizados a partir de 1590. Por ejemplo, el Codex Mexicanus, que contiene información de 1168 a 1590, en el Folio 80 muestra los glifos nueve caña y diez casa, que corresponden a 1540 y 1541. Sobre el primero se aprecia al virrey Antonio de Mendoza encaminándose, al parecer, hacia Juchipila, que se encuentra sobre el segundo glifo representado por un niño que lleva una flor sobre su cabeza. ${ }^{46}$ (Imagen 25).

Mientras tanto, la Tira de Tepechpan, que incluye hechos sucedidos entre 1302 y 1590, muestra con mayor claridad la campaña de Juchipila. En su lámina 16, Juchipila es representado como un cerro rematado por el torso de una persona, de cuya cabeza surge una flor. Este personaje porta un chimalli o rodela, dando la impresión de que el cerro se defiende de un guerrero del centro de México, ataviado con una armadura indígena, macáhuitl y rodela ${ }^{47}$ (Imagen 26).

46 El Codex Mexicano se encuentra disponible para su consulta en las páginas de la Biblioteca Digital Mundial, la Biblioteca Nacional de Francia y Amoxcalli.

47 La Tira de Tepechpan puede revisarse, tanto en su versión original (catalogada como 013-014) y en una copia posterior (088-6, aunque en su lámina 18) en Amoxcalli. 


\section{Imagen 25}

Codex Mexicanus (Folio 80)
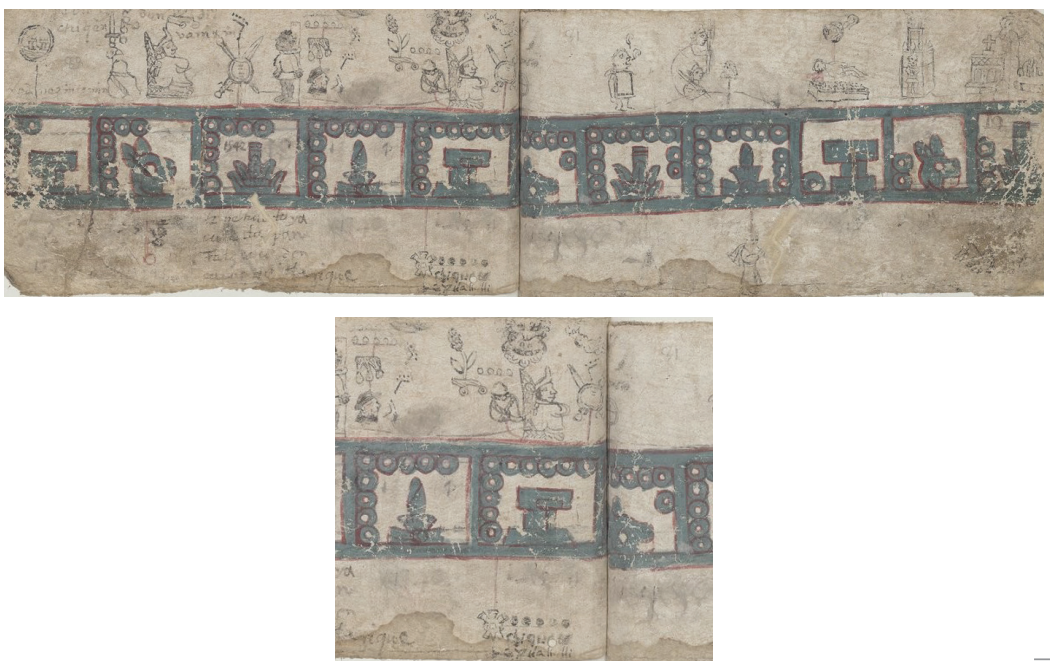

Fuente: Tomado de la Página Gallica, de la Biblioteca Nacional de Francia.

\section{Imagen 26}

Códice de Tepechpan
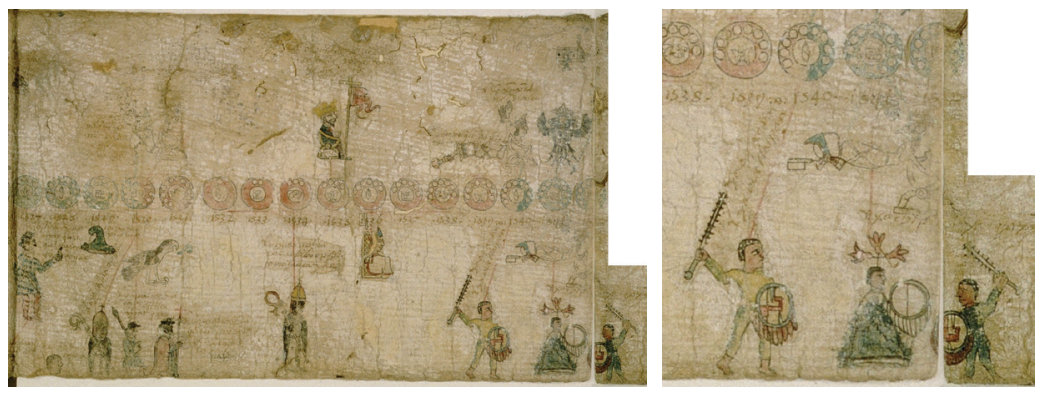

Fuente: Tomado de la Página Amoxcalli.

Por su parte, el Manuscrito Mexicano Número 40, realizado cerca de $1594^{48}$, incluye otra referencia a Juchipila. En su folio 16v aparece el año 10 casa (erróneamente situado en 1542) donde se aprecia la figura de un gobernante sentado junto al glifo calendárico y frente a el Xuchipila,

$48 \quad \begin{aligned} & \text { El Documento No. 040. Historia Mexicana desde } 1221 \text { hasta 1594, así como el análisis } \\ & \text { realizado por Elia Rocío Hernández Andón, se encuentran disponibles en Amoxcalli. }\end{aligned}$ 


\section{Imagen 27}

Manuscrito Mexicano No. 40 (Folio 16v)

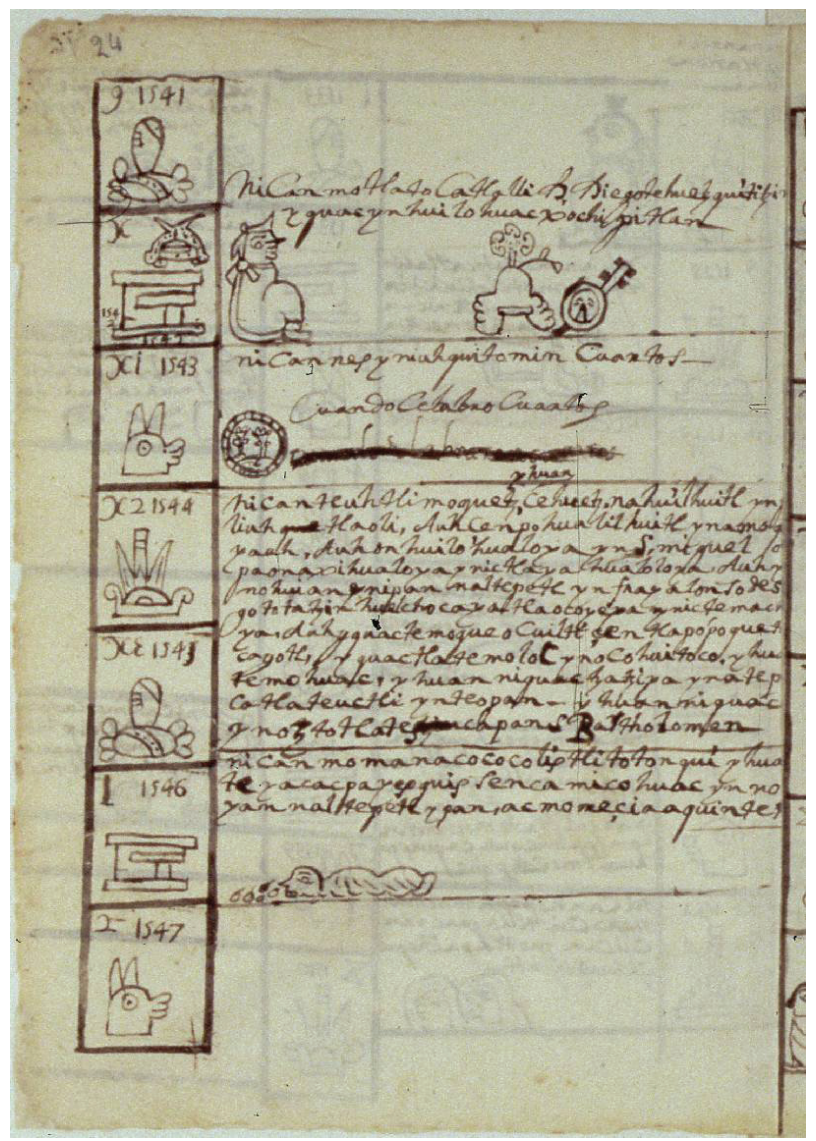

Fuente: Tomado de Hernández Andón S/ f, Amoxcalli.

representado como un cerro rematado por una flor y, junto a él, un escudo acompañado de lo que podría ser un macáhuitl o una flecha que representan una campaña bélica. Estos hechos están acompañados por la leyenda Nican motlatocatlalli D[on] Diego Tehuetzquititzin yquac yn huilohuac Xochipitlan ${ }^{49}$ (Imagen 27).

49 Hernández Andón lo traduce como: Aquí (en este año) gobernó Don Diego Tehuetzquititzin cuando todos fueron a Xochipilan, mientras que León-Portilla lo interpreta como: Aquí se estableció en el gobierno de Don Diego Tehuetzquititzin, cuando regresó de Xuchipila. 


\section{A manera de conclusión:}

\section{La Pintura del Nuevo Reino de Galicia como parte de un Relato visual}

En este trabajo presentamos la Pintura del Nuevo Reino de Galicia como un documento histórico y cartográfico, con rasgos de códice mesoamericano que reproduce una serie de acontecimientos bélicos y prácticas culturales que, al mismo tiempo, reflejan una síntesis histórica del desarrollo del Occidente de México. Por un lado muestra la expansión caxcana descrita por Tello (1968) y por otro, un parteaguas importante en el desarrollo de la Conquista, como lo fue la Guerra del Mixtón, que con los hechos bélicos ocurridos entre 1541 y 1542, se convirtió en antecedente de la Guerra Chichimeca y la continuidad de una resistencia indígena que se extendería hasta 1722, cuando se logró la conquista de los Nayaritas.

Al mostrar estos hechos de forma paralela a la expansión de los españoles, la Pintura del Nuevo Reino de Galicia se convierte en un relato visual y una herramienta política en un contexto específico. En este sentido, cumple con la función de narrar, de forma condensada y a partir de imágenes que son ambiguas y polisémicas (Burke, 2001), una serie de hechos históricos y geográficos, aunque sin brindar datos específicos sobre el orden social prevaleciente en las sociedades indígenas de la región.

Como puede apreciarse, las imágenes contenidas en la Pintura del Nuevo Reino de Galicia coinciden con la descripción de las fuentes etnohistóricas y el registro arqueológico disponible para estas sociedades, especialmente la existencia de sitios defensivos, prácticas guerreras, la desnudez y sacrificios humanos. Como se ha mencionado previamente, si lo consideramos como un códice, puede convertirse en un relato visual (Burke, 2001)

De esta forma, las imágenes se convierten en testimonio del peligro que las sociedades indígenas representaban para el avance español al concentrar la atención en ciertos hechos y espacios específicos. Así, siguiendo la lógica de Peter Burke (2001), la Pintura, aunada a las crónicas contemporáneas, jugó un papel importante en la "invención cultural" de las sociedades indígenas, a la vez que se convierte es un testimonio del orden social existente y las formas de pensar y ver las cosas por parte de los españoles y sus aliados indígenas, que trataban de mostrar la lealtad de sus servicios a la Corona. Ante este escenario, la Pintura, al igual que otros documentos sobre la Guerra del Mixtón, justificaría la violencia desplegada contra las sociedades Nayaritas, Caxcanas y Transtarascas y su resistencia al proceso colonizador. 
Tanto las crónicas como los relatos visuales reforzaron una idea de barbarie exaltada por la desnudez de los guerreros representados en la Pintura, elemento presente también en el códice Telleriano-Remensis (Imagen 18), así como el nomadismo y la aparente ausencia de complejos urbanos y ceremoniales. Esto serviría a las autoridades coloniales como argumento para sofocar la posterior Guerra Chihimeca y, finalmente, someter a las sociedades Nayaritas. Sin embargo, la Etnohistoria y la Arqueología han impugnado esta idea, por lo menos en algunos aspectos. Por un lado, la Arqueología ha mostrado el desarrollo de sociedades complejas que establecieron una arquitectura distintiva, una fuerte jerarquización social y complejas redes de comercio que, desde el clásico, conectaron la Tradición Teuchitlán (en la zona de Etzatlán-Magdalena) (Weigand 1992, 1993, 2013, 2015a, 2015b; Weigand y García 1996, 2000, 2002a, 2002b), con la Tradición Chalchichuites, dando origen a la Cultura Bolaños (Hers 1989, 1992; Cabrero 1989, 1992).

Por otro lado, la Etnohistoria, a través del análisis de fuentes permite comprender las formas de organización social, el aprovechamiento del paisaje, los productos que formaban parte del comercio y el tributo entre estas sociedades. Esto nos permite vislumbrar el paisaje político en las zonas Caxcana y Transtarasca que, durante el posclásico, frenaron su proceso expansivo ante el desarrollo de la conquista y colonización española para instaurar un nuevo orden social.

Ante esto cabe la posibilidad de que la Pintura, al igual que el Lienzo de Tlaxcala, muestre los servicios de las tropas indígenas del centro de México que acompañaron a los españoles en sus diferentes campañas. Geográficamente muestra el avance de los colonizadores españoles que, separados por el Río Santiago, buscaban penetrar a los territorios dominados por las sociedades indígenas para realizar prospección y establecer asentamientos mineros, agrícolas y ganaderos. Como herramienta política, sirvió como argumento para exaltar la aparente barbarie de las sociedades indígenas y promover su pacificación a través de las armas, pero también como razón para promover el traslado de la capital de la Nueva Galicia a Guadalajara.

Esto es sólo un primer vistazo de un trabajo más amplio en que continuaremos la discusión sobre la importancia de los datos de Martínez de la Marcha, a quien se atribuye la elaboración de la Pintura, y como estos se reflejan, en realidad en el Mapa de Ortelius, con la intención de profundizar en la forma en que, a través del refuerzo de la otredad, los documentos cartográficos y las crónicas de la época contraponen dos formas de organización sociocultural distintas. 


\section{Bibliografía}

Acuña, R. (ed) (1988)

Pintura del Nuevo Reino de Galicia. En Relaciones geográficas del siglo XVI: Nueva Galicia. México: Universidad Nacional Autónoma de México, pp: 150-151.

Acuña, R. (1988)

Relaciones geográficas del siglo xvi: Nueva Galicia. México: Universidad Nacional Autónoma de México.

Álvarez, S. (2009)

El indio y la sociedad colonial norteña. Siglos XVI-XVIII. México: Instituto de Investigaciones Históricas de la UJED-El Colegio de Michoacán, A. C.

Álvarez, S. (2016)

La primera regionalización (1530-1570). En Historia del Reino de la Nueva Galicia, Calvo, Thomas y Aristarco regalado Pinedo (coordinadores). Guadalajara: Universidad de Guadalajara, pp:165-210.

Anderson, B. 1997 (1983)

Comunidades imaginadas. Reflexiones sobre el origen y la difusión del nacionalismo. México: Fondo de Cultura Económica.

Arias y Saavedra, A. (1975)

Franciscan report on the Indians of Nayarit, 1673 (introducción de Kieran McCarthy, O.F.M.; traducción de Dan S. Matson). En Ethnohistory, No. 22, pp: 193-222.

Arias y Saavedra, A. 1986 (1673)

Información rendida por el P. Antonio Arias y Saavedra, acerca del estado de la Sierra del Nayarit, en el siglo XVII. En Santoscoy, Alberto, Obras completas, Vol. II. Guadalajara: Universidad Nacional de Educación a Distancia, pp: 973-989.

Arias y Saavedra, A. 1990 (1673)

Información rendida en el siglo XVII por el P. Antonio Arias y Saavedra acerca del estado de la sierra de Nayarit y sobre culto idolátrico, gobierno y costumbres primitivas de los coras. En Calvo, Thomas (ed.), Los albores de un nuevo mundo: siglos XVI y XVII. México: Centro de Estudios Mexicanos y Centroamericanos, pp: 283-309.

Bakewell, P. J. 1976 (1971)

Minería y sociedad en el México colonial: Zacatecas 1546-1700. México: Fondo de Cultura Económica.

Bakewell, P. J. (1990)

La minería en la Hispanoamérica colonial. En Historia de la América Latina 3. América Latina Colonial: Economía, Bethel, Leslie (ed.); Barcelona, Editorial Crítica, pp: 49-81. 
Baudot, G. 1983 (1976)

Utopía e historia en México. Los primeros cronistas de la civulización mexicana (1520-1569). Madrid: Espasa Calpe.

Baudot, G. 1990 (1983)

Prefacio: Contexto Etnohistórico. En Relatos aztecas de la conquista, Baudot, Georges y Tzevetan Todorov. México: Consejo Nacional para la Cultura y las Artes-Grijalbo, pp: 11-13.

Baus de Czitrom, C. 1982

Tecuexes y cocas. Dos grupos de la región Jalisco en el siglo XVI. México: Instituto Nacional de Antropología e Historia.

Bernabéu Albert, S. y García Redondo, J. M. (2010)

Sobre cartografía y fascinación de la frontera: el mapa de la Nueva Galicia (Circa 1550). En Poblar la inmensidad: sociedades, conflictividad y representación en los márgenes del imperio hispánico (siglos XVIXIX). Salvador Bernabéu Albert (coord.), Barcelona, Ediciones Rubeo, pp: 129-178.

Boehm, B. (1995)

Poblamiento en el Occidente de México en el mapa de Ortelius. Ponencia. Simposio sobre arqueología y etnohistoria de las cuencas del Occidente de México. Zamora: El Colegio de Michoacán.

Brand, D. (1971)

Etnohistorical synthesis of Western Mexico. En Handbook of Middle American Indians, Vol. 11. University of Texas Press, pp. 40-50.

Broda, J. (1978)

El ambiente socio-cultural e intelectual de los cronistas y la crítica de las fuentes del siglo XVI. En Apuntes de Etnohistoria, Escuela Nacional de Antropología e Historia, Época 1, Vol. 2, No. 2, pp: 5-20.

Burke, P. (2001)

Visto y no visto. El uso de la imagen como documento histórico. Barcelona: Crítica.

Bustamante, J. (2009)

El indio americano y su imagen. La construcción de un arquetipo: el salvaje emplumado. En De la barbarie al orgullo nacional. Indígenas, diversidad cultural y exclusión. Siglos XVI al XIX, Soto Estrada Miguel y Mónica Hidalgo Pego (coords.). México: Universidad Nacional Autónoma de México, pp: 19-73.

Cabrero G., Ma. T. (1989)

Civilización en el norte de México: arqueología de la cañada del río Bolaños (Zacatecas y Jalisco). Ciudad de México: Universidad Nacional Autónoma de México. 
Cabrero G., Ma. T. (1992)

La cultura Bolaños como respuesta a una tendencia expansiva. En Origen y desarrollo de la civilización en el Occidente de México. México: El Colegio de Michoacán A. C., pp: 339-358.

Calvo, T. y Machuca, P. (2016)

Un actor ineludible: entre sierras y cuencas. En Historia del Reino de la Nueva Galicia; Calvo, Thomas y Aristarco regalado Pinedo (coordinadores). Guadalajara: Universidad de Guadalajara, pp: 33-57.

Carrillo Cázares, A. (2000)

El debate sobre la Guerra Chichimeca, 1531-1585. Dos volúmenes. Zamora: El Colegio de Michoacán-El Colegio de San Luis.

Chevalier, F. 1999 (1953)

La formación de los latifundios en México. Haciendas y sociedad en los siglos XVI, XVII y XVIII. México: Fondo de Cultura Económica.

Ciudad Real, A. de, 1976 (1586)

Tratado curioso y docto de las grandezas de la Nueva España. Relación breve y verdadera de algunas cosas de las muchas que sucedieron al padre fray Alonso Ponce en las provincias de la Nueva España siendo comisario general de aquellas partes. Dos tomos. México: Universidad Nacional Autónoma de México.

Contreras, D. (2014)

Teodoro de Bry. Constructor de la imagen del nuevo mundo. Santiago de Chile: Ediciones Oxímoron.

Enciso Contreras, J. (2016)

La audiencia de la Nueva Galicia durante sus primeras etapas. Retrato institucional. En Revista Mexicana de Historia del Derecho, xxxII, pp: 3-22.

Escalante Gonzalbo, P. (1998)

Los Códices. México: Consejo Nacional para la Cultura y las Artes.

Escalante Gonzalbo, P. (2010)

Los códices mesoamericanos antes y después de la conquista española. México: Fondo de Cultura Económica.

Fernández Díaz, R. (2014)

Códice Aubin 1576. En Arqueología Mexicana, Códices mexicanos en la Biblioteca Nacional de Francia, Edición especial 54, pp: 32-35.

Galarza, J. (1986)

Amatl, Amoxtli. El papel, el libro. México: Tava Editorial, S. A.

Galarza, J. (1992)

In amoxtli in tlacatl. El libro, el hombre. México: Tava Editorial, S. A.

Galarza, J. (1996)

Tlacuiloa. Escribir pintando. México: Tava Editorial, S. A. 
Galindo y Villa, J. 1980 (1925)

Códice Mendoza o Códice Mendocino. México: Editorial Innovación.

Gerhard, P. (1986)

Geografía histórica de la Nueva España, 1519-1821. México: Universidad Nacional Autónoma de México.

Gerhard, P. 1996 (1982)

La frontera Norte de la Nueva España. México: Universidad Nacional Autónoma de México.

Gómez de Maraver, P. (2000a)

Carta de (...) al Rey, México, 1 de junio de 1544. En Carrillo Cázares, Alberto El debate sobre la Guerra Chichimeca, 1531-1585. Dos volúmenes. Zamora: El Colegio de Michoacán-El Colegio de San Luis, pp: 470-475.

Guzmán, Nuño de 1963 (1530)

Carta a S. M. Del precidente de la Audiencia de Mejico, Nuño de Guzmán, en que refiere la jornada que hizo a Mechoacan, a conquistar la provincia de los tebles Chichimecas que confina con Nueva España. MDXxx. En Crónicas de la conquista del Reino de la Nueva Galicia en territorio de la Nueva España, Razo Zaragoza, José Luís (Comp.). Guadalajara: H. Ayuntamiento de la Ciudad de Guadalajara-Instituto Jalisciense de Antropología e Historia, pp: 21-59.

Hernández Andón, E. R. (2004)

La representación pictográfica de elementos hidrológicos e hidraúlicos en las Relaciones Geográficas del siglo XVI. Tesis de Maestría: Universidad Nacional Autónoma de México.

Hers, M.-A. (1989)

Toltecas en tierras chichimecas. México: Universidad Nacional Autónoma de México.

Hers, M.-A. (1992)

Colonización Mesoamericana y patrón de asentamiento en la Sierra Madre Occidental. En Origen y desarrollo de la civilización en el Occidente de México. México: El Colegio de Michoacán A. C., pp: 103-135.

Hers, M.-A. (2008)

Tradición huichola y Arqueología en la región de Huejuquilla, Jalisco. En Estudios Jaliscienses, No. 71, pp: 5-25.

Hers, M.-A. (2010)

El sacrificio humano entre los Tolteca-Chichimecas: los antecedentes norteños de las prácticas Toltecas y Mexicas. En López Luján, Leonardo y Guilhem Olivier (Coords.) El sacrificio humano en la tradición religiosa mesoamericana, pp: 227-246. 
Hillerkuss, T. (2006)

La Guerra de Miztón (1541) a la luz de nuevas fuentes. En Memorias del Primer encuentro de especialistas sobre la región Norte de Jalisco (CD). Colotlán: Universidad de Guadalajara.

Hillerkuss, T. (2013)

Las minas de la Nueva España en los mapas del siglo XVI. ¿Un secreto de Estado?. En Apuntes, Vol. 26, Num. 1, Enero-Junio. Bogotá, pp: 1025.

Lameiras, J. (1985)

Los déspotas armados. Un espectro de la guerra prehispánica. México: El Colegio de Michoacán.

Lameiras, J. (1994) El encuentro de la piedra y el acero. La Mesoamérica militarista del siglo XVI que se opuso a la irrupción europea. Michoacán: El Colegio de Michoacán.

Langenscheidt, A. (2009)

El aprovechamiento del oro en el área Mesoamericana. En Arqueología 41, mayo-agosto, pp: 132-147.

León-Portilla M. (1995)

La flecha en el Blanco. Francisco Tenamaztle y Bartolomé de las Casas en la lucha por los derechos de los indígenas 1541-1556. México: El Colegio de Jalisco-Diana.

López Austin, A. (1985)

La educación de los antiguso nahuas. Dos volúmenes. México: Secretaría de Educación Pública-Ediciones El Caballito

López Gutiérrez, A. J. (2004)

Guadalajara y Sevilla. Dos ciudades hermanas en el reino de Nueva Galicia. H. Ayuntamiento Constitucional de Guadalajara-Fundación El Monte.

López Guzmán, R. (2008)

Nueva Galicia en las relaciones geográficas de Felipe II: aspectos urbanos. En Quintana. Revista de Estudos de Departamento de Historia da Arte, No. 7. España: Universidad de Santiago de Compostela, pp: 117-135.

Martínez de la Marcha, H. (2000)

Carta de Hernán Martínez de la Marcha al Rey, Compostela, 18 de febrero de 1551. En Carrillo Cázares, Alberto El debate sobre la Guerra Chichimeca, 1531-1585. Dos volúmenes. Zamora: El Colegio de Michoacán-El Colegio de San Luís, pp: 479-487.

Medrano Enríquez, A. M. (2001)

Evidencias de prácticas culturales entre los Caxcanes. Un estudio de caso. En Estudios de Antropología Biológica, X, pp: 455-472. 
Medrano Enríquez, A. M. (2012)

Arqueología del conflicto. La Guerra del Mixtón (1541-1542) vista a través del Peñol de Nochistlán. Zacatecas: Taberna Literaria Editores.

Medrano Enríquez, A. M. (2014)

Campos de batalla en México: Arqueología y patrimonio militar. En Sobre campos de batallas: Arqueología de conflictos bélicos en América Latina, Landa, Carlos Gilberto y Odlanyer Hernández de Lara. Buenos Aires: Aspha, pp: 49-74.

Meyer, J. (1989)

El Gran Nayar. México: INI-Centro de Estudios Mexicanos y Centroamericanos.

Mohar Betancourt, L. M. (1997)

Manos artesanas del México Antiguo. México: Secretaría de Educación Pública-Consejo Nacional de Ciencia y Tecnología.

Mohar Betancourt, L. M. (2004)

Códice Mapa Quinatzin. Justicia y derechos humanos en el México antiguo. México: Comisión Nacional de los Derechos Humanos-Centro de Investigaciones y Estudios Superiores en Antropología Social-Miguel Angel Porrúa.

Morales Folguera, J. M. (2003)

La ciudad hispanoamericana en el siglo xVI. En $V$ Centenario del primer viaje a América de Bartolomé de las Casas (1502-2002). Sevilla: Junata de Andalucía, pp: 33-51.

Motolinia, Fray Toribio de Benavente o... (1984)

Historia de los indios de la Nueva España. México: Editorial Porrúa.

Muñoz Camargo, D. (2000)

Descripción de la ciudad y provincia de Tlaxcala. México: El Colegio de San Luís-Gobierno del Estado de Tlaxcala.

Nuttall, Z. 1875 (1902)

The Codex Nuttall. A Picture Manuscript from Ancient Mexico. New York: Dover Poblations Inc.

Orendain, L. I. (1961)

Mapa del Obispado de Compostela. En Cartografía de la Nueva Galicia. Guadalajara: Ediciones del Banco Industrial de Jalisco, pp: 30-31.

Ortega, J. 1944 (1754)

Maravillosa reducción y conquista de la provincia de S. Joseph del Gran Nayar. En Apostólicos afanes de la Compañía de Jesús escritos por un padre de la misma sagrada religión. México: Ed. Layac.

Ortega, J. (1996)

Maravillosa reducción y conquista de la provincia de S. Joseph del Gran Nayar, nuevo Reino de Toledo. En Apostólicos afanes de la Com- 
pañía de Jesús escritos por un padre de la misma sagrada religión. México: Instituto Nacional Indigenista-Centro Frances de Estudios Americanos y Centroamericanos.

Páez Brotchie, L. 1957 (1932)

El mapa auténtico más antiguo. En Guadalajara de Indias. Guadalajara: Ediciones del Banco Industrial de Jalisco, pp: 157.

Pacheco Urista, L. Y. y González Rizo, J. E. (2017)

Entre el silencio y el olvido: Prácticas agrohidráulicas prehispánicas en la cuenca de Magdalena, Jalisco. En Letras Históricas Número 15, Otoño 2016-invierno 2017. Méxcico: Universidad de Guadalajra, pp: 17-41.

Parry, J. H. 1993 (1948)

La Audiencia de Nueva Galicia en el siglo XVI. Zamora: El Colegio de Michoacán A. C.-Fideicomiso Teixidor.

Pérez Rocha, E. (2012)

Códice Tlatelolco. En Arqueología Mexicana. La Colección de códices de la Biblioteca Nacional de Antropología e Historia. Edición Especial 42. pp: 66-69.

Pizano y Saucedo, C. (1964-1965)

El puerto de la Navidad y la expedición de Legazpi. En Historia Mexicana XIV, no. 54, pp: 227-249.

Powell, P. W. 1996 (1975)

La Guerra Chichimeca. 1550-1600. México: Fondo de Cultura Económica.

Puga, Vasco de 1985 (1563)

Cedulario de la Nueva España, edición faccisimilar. México: Centro de Estudios de Historia Condumex.

Ramírez Flores, J. (1968)

Viajes de Fray Alonso Ponce al Occidente de México. Guadalajara:

Corresponsalía del Seminario de Cultura Mexicana Guadalajara.

Razo Zaragoza, J. L. (2001)

Crónicas de la conquista del Reino de la Nueva Galicia en territorio de la Nueva España. Guadalajara: Gobierno de Jalisco-Instituto Jalisciense de Antropología e Historia.

Rivera Villanueva, J. A. y Berumen Félix, C. S. (2011)

Documentos de los tlaxcaltecas en la Nueva Galicia y Nueva Vizcaya, siglos XVI-XVIII, Vol. 5, Gobierno del Estado de Tlaxcala, Fideicomiso Colegio de Historia de Tlaxcala, El Colegio de San Luís A. C., México (Biblioteca Tlaxcala. Fondos Documentales).

Robertson, Donald 1994 (1959) Mexican Manuscript Painting of the Early Colonial Period. The Metropolitan Schools, Norman, University of Oklahoma Press. 
Rojas, B. (1994)

De la Conquista a la Independencia. En Breve Historia de Aguascalientes. México: Fondo de Cultura Económica-El Colegio de México, pp: 13-76.

Rojas, B. (1999)

Cartografía ¿para que? Nueva España 1725-1800. En Relaciones 79, Verano, Vol. XX, pp: 219-247.

Román Gutiérrez, J. F. (2004)

Cultura material en Nueva Galicia durante el siglo XVI. En Guadalajara y Sevilla. Dos ciudades hermanas en el Reino de Nueva Galicia, López Gutiérrez, Antonio J. (Coord.). Ayuntamiento Constitucional de Guadalajara-Fundación El Monte, pp: 73-97.

Ruiz Medrano, E. (1994a)

Versiones sobre un fenómeno rebelde: la guerra del Mixtón en Nueva Galicia. En Contribuciones a la arqueología y etnohistoria del Occidente de México. Zamora, Michoacán: El Colegio de Michoacán A. C., pp: 355-378.

Ruiz Medrano, E. (1994b)

El exilio del vencido: la información de don Francisco Tenamaztle, ponencia presentada en el Coloquio Mesoamérica y la Guerra del Miztón. Instituto Nacional de Antropología e Historia-Universidad Autónoma de Zacatecas-El Colegio de Jalisco.

Santoscoy, A. 1986 (1890)

Nayarit. Colección de documentos inéditos, históricos y etnográficos, acerca de la sierra de ese nombre. En Obras completas, Vol. II. Guadalajara: Universidad Nacional de Educación a Distancia, pp: 913-989.

Taussig, M. T. 1993 (1980)

El diablo y el fetichismo de la mercancía en Sudamérica. México: Nueva Imagen.

Téllez Lozano, V. M. (2005)

Territorio, gobierno local y ritual en Xatsitsarie/ Guadalupe Ocotán, tesis Doctoral, El Colegio de Michoacán A. C.

Téllez Lozano, V. M. (2006)

La reorganización del recinto ceremonial (Tukipa) huichol de Guadalupe Ocotán, Nayarit. Reporte de la investigación patrocinada por The Foundation for the advancement of Mesoamerican Studies Inc. (FAMSI). Disponible en línea: www.famsi.org/reports/05083es/index.html

Téllez Lozano, V. M. (2010)

La organización política y ceremonial de los huicholes en el contexto de las sociedades Nayaritas. En Phil Weigand Moore. Reconocimiento Tenamaztle 2009, Heredia, Verenice y Víctor Téllez (Coords.). Guada- 
lajara: Centro Universitario del Norte, Universidad de Guadalajara, pp: 63-86.

Téllez Lozano, V. M. (2011a)

Procesos de reorganización política y ceremonial en territorio huichol: el tuki de Xatsitsarie. En Mesoamérica. Debates y Perspectivas. El Colegio de Michoacán A. C. pp: 265-291.

Téllez Lozano, V. M. (2011b)

Xatsitsarie. Territorio, gobierno local y ritual en una comunidad Huichola. Zamora: El Colegio de Michoacán A. C.

Téllez Lozano, V. M. (2011c)

Tukipa: los recintos ceremoniales como fundamento del territorio, patrimonio histórico y cultural de los huicholes. En La antropología y el patrimonio cultural de México. Dirección de Estudios HistóricosConsejo Nacional para la Cultura y las Artes. pp: 129-187.

Tello, A. (1968)

Crónica miscelánea de la Santa Provincia de Xalisco. Libro segundo, Vol. I. Guadalajara: Gobierno del estado de Jalisco-Universidad de Guadalajara.

Tello, A. (1973)

Crónica miscelánea de la Santa Provincia de Xalisco. Libro segundo, Vol. II. Guadalajara: Gobierno del estado de Jalisco-Universidad de Guadalajara.

Torre, M. de la (Ed.) (1983)

El lienzo de Tlaxcala. México: Edición privada de Cartón y Papel de México S. A. De C. V.

Valle, P. (2010)

Códice Tlatelolco. En Arqueología Mexicana, Vol. XV, No.89, pp: 6670.

Viejo, M. J. y Román Gutiérrez, J. F. (1992)

Nueva España a mediados del Siglo XVI. Colonización y expansión. En Congreso de historia del Descubrimiento (1492-1556), Tomo II. Madrid: Real Academia de Historia-Confederación Española de Cajas de Ahorros, pp: 607-664.

Weigand P. (1992)

Ensayos sobre el gran Nayar. Entre coras, huicholes y tepehuanos. México: INI-Centro de Estudios Mexicanos y Centroamericanos-ColMich.

Weigand P. (1993)

Evolución de una civilización prehispánica. Zamora: El Colegio de Michoacán A. C.

Weigand P. (1994) 
Obras hidráulicas a gran escala en el Occidente de Mesoamérica. En Contribuciones a la arqueología y etnohistoria del Occidente de México. Zamora: El Colegio de Michoacán, pp: 227-277.

Weigand P. (1996)

Las chinampas prehispánicas del Occidente de Jalisco. En Antropología. Una visión actual 3. Guadalajara: Secretaría de Cultura de Jalisco. Weigand P. (2013)

Archaeology and Etnohistory of Etzatlán an its región. En Coresspondence Analysis and West Mexico Archaeology. University of New Mexico Press, pp: 17-66.

Weigand P. (2015a)

Territory and resistance in West-Central Mexico, Part 1: Introduction and Archaelogical Background. In From tribute to comunal sovereignty. The Tarascan and Caxcan Territories in transition, Roth-Seneff, Andrew, Robert V. Kemper y Julie Adkins (Eds.). Estados Unidos: The University of Arizona Press, pp: 43-70.

Weigand P. (2015b)

Territory and resistance in West-Central Mexico, Part 2: The Rebelion de Nueva Galiciaand itsLate Postclassic Prelude. In From tribute to comunal sovereignty. The Tarascan and Caxcan Territories in transition, Roth-Seneff, Andrew, Robert V. Kemper y Julie Adkins (Eds.). Estados Unidos: The University of Arizona Press, pp: 71-90.

Weigand, P. C. y De Weigand, Acelia G. (1995)

Los orígenes de los caxcanes y su relación con la guerra de los nayaritas. Una hipótesis. Guadalajara: El Colegio de Jalisco.

Weigand, P. C. y De Weigand, Acelia G. (1996)

Tenamaxtli y Guaxicar. Las raíces profundas de la rebelión de Nueva Galicia. Zamora: El Colegio de Michoacán.

Weigand, P. C. y De Weigand, Acelia G. (2000)

Huichol Society before the Arrival of the Spanish. En Journal of the Southwest 42 (1): 13-36.

Weigand, P. C. y De Weigand, Acelia G. (2002a)

La sociedad de los huicholes antes de la llegada de los españoles. En Estudio histórico y cultural sobre los huicholes. México: Universidad de Guadalajara, pp: 43-68.

Weigand, P. C. y De Weigand, Acelia G. (2002b)

Los huicholes y su búsqueda del peyote: ¿reliquia sacra de una antigua ruta comercial?. En Estudio histórico y cultural sobre los huicholes. México: Universidad de Guadalajara, pp: 79-91.

Weigand, P. y Romero Solís, J. M. (2000)

El fin del mundo y la formación de uno nuevo. Ensayo-reseña de Socie- 
dades en Construcción: La Nueva Galicia según las visitas de oidores (1606-1616). En Relaciones 84, Otoño, Vol. XXI, pp: 273-281.

Wolf, E. 1987 (1982)

Europa y la gente sin historia. México: Fondo de Cultura Económica. Yáñez, R. (1993)

Historiografía y Antonio Tello. Ponencia, Coloquio de Occidentalistas, Universidad de Guadalajara.

Yáñez, R. (2001)

Rostro, palabra y memoria indígenas. El Occidente de México: 15241816. Guadalajara: Centro de Investigaciones y Estudios Superiores en Antropología Social-INI.

\section{Referencias en internet}

Amoxcalli http://amoxcalli.org.mx/codice.php?id=023-024

Biblioteca Nacional de Francia http://gallica.bnf.fr/ark:/12148/ btv1b55005834g

Códice Aubin de 1576 o Historia de la Nación mexicana, Museo Británico http://www.britishmuseum.org/research/collection_online/collection_object_details/collection_image_gallery.aspx?assetId=17821300 1\&objectId=3008812\&partId=1

Códice Ríos (Vaticano A-3738): http://pueblosoriginarios.com/meso/valle/azteca/codices/rios/rios.html.

Códice Telleriano-Remensis, http://www.famsi.org/spanish/research/ loubat/Telleriano-Remensis/thumbs0.html.

Crespo, Raquel s/ f Códice Mendoza, en: Proyecto Tetlacuilolli : http:// www.tetlacuilolli.org.mx/codice.php?id=1198292015

El Codex Mexicano, Biblioteca Digital Mundial https://dl.wdl.org/15284/ service/15284.pdf

Hernández Andón, Elia Rocío Documento No. 040. Historia Mexicana desde 1221 hasta 1594, http://amoxcalli.org.mx/facsimilar.php?id=040

Lienzo de Tlaxcala Número 3 http://codices.inah.gob.mx/pc/index.php

Mapa de la Nueva Galicia, Portal de Archivos Españoles. Ministerio de Educación, Cultura y Deporte del Gobierno de España: http://pares. mcu.es/ParesBusquedas/servlets/Control_servlet?accion=3\&\&txt_ tipo_busqueda=dl\&txt_busqueda $=\&$ txt_correo=S\&txt_id_desc_ $\mathrm{ud}=21517$

Mapa de la Ciudad de Compostela y una parte del territorio de la Nueva Galicia, Biblioteca Digital de la Real Academia de Historia, http://bibliotecadigital.rah.es/dgbrah/es/consulta/registro.cmd?id=15863

Mohar Betancourt, Luz María El Códice Mendoza o Mendocino, http:// www.tetlacuilolli.org.mx/elementos/codice/pdf/1198292015.pdf 
Provanzas hechas por parte de la ciudad de Guadalajara y otros pueblos de Nueva Galicia en el pleito suscitado entre los obispos de la Nueva Galicia y Michoacán, sobre demarcación de sus límites y mudar la silla de la ciudad de Guadalajara a la de Compostela http://pares.mcu. es/ParesBusquedas/servlets/Control_servlet?accion=3\&\&txt_tipo_ busqueda=dl\&txt_busqueda=\&txt_correo=S\&txt_id_desc_ud $=93241$.

Tira de Tepechpan (013-014, lámina 16): http://amoxcalli.org.mx/zoom. php?ri=codices/013-014/laminas/013-014_16.jpg http://amoxcalli.org.mx/laminas.php?id=013-014\&ord_lamina=013014_16\&act $=$ con

Tira de Tepechpan (copia), (088-6, lámina18): http://amoxcalli.org.mx/laminas.php?id=088_6\&act $=$ sig\&ord_lamina $=088 \_6 \_17$ 